PONTIFÍCIA UNIVERSIDADE CATÓLICA DO RIO DE JANEIRO

Estudo sobre o Comportamento de Consumo Consumo de Livros na Amazon pela Geração Z

Ana Beatriz Antunes Pinheiro

Trabalho de Conclusão de Curso

CENTRO de CIÊNCIAS SOCIAIS - CCS

DEPARTAMENTO DE ADMINISTRAÇÃO

Graduação em Administração de Empresas 
Ana Beatriz Antunes Pinheiro

\section{Estudo sobre o Comportamento de Consumo Consumo de Livros na Amazon pela Geração Z}

Trabalho de Conclusão de Curso

Trabalho de Conclusão de Curso, apresentado ao programa de graduação em Administração da PUC-Rio como requisito parcial para a obtenção do título de graduação em Administração.

Orientador(a) : Vivian Steinhäuser

Rio de Janeiro

Julho de 2021. 
Para minha mãe, Renata, por ter despertado em mim a paixão pelos livros e meu pai, Francisco, por a ter incentivado. $O$ fruto disso está aqui e na imensa biblioteca que temos em casa. 


\section{Agradecimentos}

Primeiramente, gostaria de agradecer às pessoas que contribuíram para a realização deste trabalho.

Aos professores do IAG, por compartilharem conosco seus conhecimentos e pelo incentivo durante toda a caminhada acadêmica. À minha orientadora Vivian Steinhäuser especialmente que, com imensa paciência e sabedoria, fez com que a jornada para a conclusão dessa monografia fosse leve e construtiva.

Às minhas amigas da faculdade, Bruna Trindade, Isabelle Nantes e Fernanda Mafra. Sem vocês os trabalhos em grupo com certeza teriam sido muito menos divertidos. Obrigada pela companhia e apoio. Vocês são grandes presentes que a PUC-Rio me deu.

À minha família de forma geral, pelo imenso apoio e incentivo durante toda a minha vida. Meus momentos de maior felicidade foram os que passamos juntos. Obrigada por isso também.

Aos meus pais, Francisco Artur e Renata, pelo mundo de oportunidades que deram a mim e aos meus irmãos ao longo da nossa vida, mas principalmente pela infinita quantidade de amor e carinho sempre dedicados a nós. A vocês meu amor e gratidão eternos.

Aos meus irmãos, João Ricardo e Luiz Eduardo. Apesar de me irritarem grande parte das vezes, não consigo imaginar um dia da minha vida sem vocês.

À minha irmã, Juliana, que com toda a paciência do mundo leu e releu esta monografia, a fim de me auxiliar na missão de entregar o melhor trabalho possível. Obrigada por isso, e por ter me escolhido há 25 anos para desempenhar um papel tão importante.

Aos meus avós, paternos e maternos, pelos diversos ensinamentos. À minha avó Nelly, pelas diversas aulas de português e pelas constantes "paparicações" e meu avô Avelino, pela confiança depositada em mim quando me delegou parte tão importante do projeto de sua vida. O meu amor por vocês é sem fim.

Aos meus tios Annie, Ricardo e Ita, e meus primos Fernanda e Leonardo. Vocês tornam todos os momentos mais especiais e leves. Obrigada por serem fonte uma fonte de carinho inesgotável. 
Às minhas amigas e amigos, em especial Gabriela Guarçoni, Amanda Pontes, Carolina Riccieri, Carolina Dias e Carolina Michels. Vocês se enquadram na categoria família. Obrigada pelas risadas, conselhos, apoio, viagens e por sempre estarem presente, mesmo quando essa presença só é possível através de ligações de vídeo.

À Luciana, pelo apoio e torcida constante. Nossas conversas incentivaram a melhor mudança que fiz em minha vida. Obrigada por isso.

E, finalmente, agradeço a Deus, por ser fonte de sustento e meu maior ouvinte. Obrigada por me socorrer nas horas em que mais precisei. 
"Não há limite para o que nós, como mulheres, podemos alcançar."

(Michelle Obama) 


\section{Resumo}

ANTUNES PINHEIRO, Ana Beatriz. Estudo sobre o Comportamento de Consumo: Consumo de Livros na Amazon pela Geração Z. Rio de Janeiro, 2021. 32 p. Trabalho de Conclusão de Curso - Departamento de Administração. Pontifícia Universidade Católica do Rio de Janeiro.

O presente estudo tem como objetivo analisar o comportamento do consumidor na compra de livros físicos de romance na Amazon por pessoas da geração Z, moradores da cidade do Rio de Janeiro e quais são os principais motivadores que os levam a realizar tais compras. O estudo foi realizado com consumidores de livros de romance do e-commerce, com idades variando de 28 a 19 anos. Para isso, foi elaborada uma pesquisa exploratória qualitativa e foram feitas entrevistas através de chamadas de vídeo para a coleta das informações. Demonstra-se através do estudo que consumidores da geração $Z$ possuem um perfil bastante similar entre si em diversos aspectos, apesar de não ser muito definido, já que possuem diferentes características e preocupações no momento da compra.

\section{Palavras- chave}

Comportamento do Consumidor, Geração Z, Livros, Romance, Amazon, Consumo, Comércio Eletrônico.

\section{Abstract}

ANTUNES PINHEIRO, Ana Beatriz. Study on Consumption Behaviour: Consumption of Books on Amazon By Generation Z. Rio de Janeiro, 2021. 32 p. Course Conclusion Paper - Administration Department. Pontificial Catholic University of Rio de Janeiro.

This study aims to analyze consumer behavior in the purchase of physical books of romance on Amazon by people of generation Z, residents of the city of Rio de Janeiro and what are the main motivators in purchases made through the channel. The study was carried out with consumers of e-commerce romance books, with ages varying from 28 to 19 years old. For this, a qualitative exploratory research was carried out and interviews were made through video calls to collect the information. It was concluded through it that generation $\mathbf{Z}$ consumers have a very similar profile to each other in several aspects, despite not being very defined, since they have different characteristics and concerns at the time of purchase. 


\section{Key-words}

Consumer Behavior, Generation Z, Books, Romance, Amazon, Consumer, E-Commerce. 


\section{Sumário}

1 O Tema do Estudo 1

1.1. Introdução ao tema e problema do estudo 1

1.2. Objetivo do Estudo 3

1.3. Objetivos Intermediários do Estudo 4

1.4. Foco e Delimitação 4

1.5. Relevância 4

2 Referencial Teórico $\quad 6$

2.1. Comportamento do Consumidor 6

2.1.1. Comportamento do Consumidor de Literatura no Brasil 7

2.1.2. Comportamento do Consumidor Virtual 10

2.1.2.1. Comportamento do Consumidor no ambiente digital durante a Pandemia do Corona Vírus 13

2.1.2.2. Expectativa para o Comportamento do Consumidor no ambiente $\begin{array}{ll}\text { digital após a Pandemia do Corona Vírus } & 15\end{array}$

2.1.3. Impacto da Amazon no Comportamento de Compra 16

2.2. Geração Z 17

2.2.1. Comportamento de Compra da Geração Z no ambiente online 18

3 Metodologia 20

3.1. Etapas de coleta de dados 20

3.2. Fontes de Informações selecionadas para a coleta de dados no estudo 20

3.3. Procedimentos e instrumentos de coleta de dados utilizados no $\begin{array}{ll}\text { estudo } & 21\end{array}$

3.4. Limitações do Estudo $\quad 21$

4 Análise das Respostas $\quad 22$

4.1. Perfil dos Entrevistados 22

4.2. Comportamento do Consumidor da Geração Z na Amazon 23 
4.3. Motivações que levam o consumidor da geração $Z$ a comprar livros físicos online 26

4.3.1. Motivação para a compra de livros através da Amazon 27

4.4. Inibidores de Compras Online 28

5 Conclusões 29

5.1. Conclusão final dos estudos sob a perspectiva da pesquisa e entrevistas 29

5.2. Sugestões e recomendações para novos estudos 32

6 Referências 33

$\begin{array}{ll}\text { Anexo } 1 & 36\end{array}$

$\begin{array}{ll}\text { Anexo } 2 & 37\end{array}$

\section{Lista de figuras}

Figura 1: Dados sobre o uso do tempo livre de leitores..................................... 8

Figura 2: Preferência de formato entre os leitores ........................................... 8

Figura 3: Modo de aquisição e formato do último livro dos leitores entrevistados 9

Figura 4: Resultados sobre a escolha de sites e aplicativos utilizados nas compras pela internet..................................................................... 11

Figura 5: Pesquisa com produtos comprados de forma não planejada.............. 12

Figura 6: Pesquisa sobre importância da facilidade na navegação em sites de

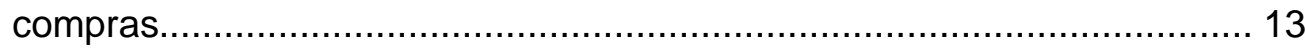

Figura 7: Pesquisa sobre comportamento de compra no cenário pós pandêmico. 


\section{Lista de Tabelas}

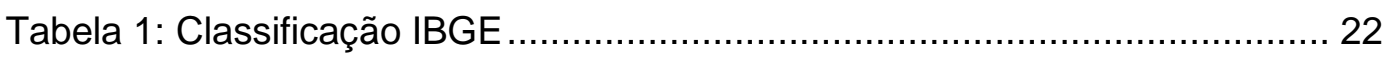

Tabela 2: Dados dos Entrevistados..................................................... 23 


\section{Tema do Estudo}

Ao longo deste estudo, é abordado o comportamento do consumidor da geração Z, ou seja, pessoas nascidas entre 1990 e 2010, na compra de livros físicos de romance na Amazon.

Outros pontos que serão levantados são os motivos que levaram a uma expansão do comércio eletrônico no último ano, com o impacto do isolamento social causado pela pandemia do COVID-19, e como esse mercado vem se tornando o canal de compras mais usado pelas pessoas da geração $Z$.

\subsection{Introdução ao tema e problema do estudo}

Um dos grandes acontecimentos dos últimos tempos foi o surgimento da Internet. Ela impactou diversas áreas da vida das pessoas. Mudou a forma com que nos comunicamos, a forma com que acessamos informações e buscamos conhecimento.

Outro ponto que a internet acabou afetando foi a forma que consumimos, a forma que compramos. Houve o surgimento do e-commerce, que representou para diversas empresas um potencial de gerar mais vendas, para os consumidores representou mais vantagens, além de abrir possibilidades de novos negócios que antes não existiam (DINIZ, 1999).

Por volta de 1995, o comércio eletrônico começou a crescer significativamente nos Estados Unidos, com o surgimento de diversas empresas. Esse foi o ano em que a Amazon foi fundada.

Segundo o livro A loja de tudo: Jeff Bezos e a Era da Amazon, de Brad Stone, que conta a história da companhia e seu fundador, a empresa que fica baseada até hoje em Seattle, no estado de Washington, vendia apenas livros físicos nos seus primeiros anos de operação. Entretanto, com o passar do tempo, a empresa passou a incluir em seu catálogo outros produtos, como roupas, eletrônicos, brinquedos, e atualmente, até mesmo dispositivos próprios.

Já no Brasil, o e-commerce teve seu início cerca de cinco anos depois, no ano 2000. Desde então, as vendas por esse tipo de canal vêm crescendo, principalmente devido à conveniência e ao menor custo dos produtos, quando ofertados neste canal. (FELIPINI, 2012)

A Amazon, entretanto, chegou no Brasil apenas em 2012, quando a quarta geração do Kindle, dispositivo próprio da Amazon que permite que seus usuários leiam livros digitais, foi lançada. Quando chegou no país, apenas livros digitais 
para o aparelho eram comercializados pela empresa. Dois anos depois, a companhia então passou a comercializar também livros físicos no país.

Com o crescimento da adesão de brasileiros ao marketplace ${ }^{1}$, a Amazon então passou a expandir seu catálogo. Em 2017, permitiu que outros lojistas vendessem seus produtos no site, fazendo com que o número de acesso e oportunidades de negócio crescessem.

Para a empresa, até hoje os livros são um dos produtos mais vendidos. Durante o primeiro Prime Day no Brasil, dia em que assinantes Prime ${ }^{2}$ da companhia tem direito a ofertas exclusivas, além do frete grátis, os livros foram um dos produtos listados como um dos mais comprados, segundo entrevista de Alex Szapiro 3 para a Revista Istoé.

No ano de 2020, o mundo inteiro sentiu o impacto da pandemia do Corona Vírus. $\mathrm{O}$ isolamento social imposto em todos os países e que começou no Brasil no mês de março, teve um grande impacto na forma de consumo, principalmente por limitar o passeio de pessoas e abertura de lojas.

Em agosto de 2020, segundo a pesquisa sobre os impactos da Covid-19 no comportamento de consumo dos brasileiros da consultoria de gestão estratégica Kearnet, foi projetado um faturamento de $R \$ 111$ bilhões em 2020 para o e-commerce. Esse valor é $49 \%$ mais alto do que o valor registrado no ano anterior, quando o comércio eletrônico faturou cerca de $\mathrm{R} \$ 75$ bilhões, nos mostrando como houve um salto nesse canal de vendas no úlitmo ano, impulsionado principalmente pelo isolamento social imposto.

A Geração Z, que representa cerca de $20 \%$ da população brasileira, segundo estatística apresentada pela Organização das Nações Unidas ${ }^{4}$ em 2018, é uma fatia importante do mercado e possui um potencial de consumo elevado. Muitas vezes são retratados como a geração "nativa digital", como

\footnotetext{
${ }^{1}$ Marketplace, segundo o site E-commerce Brasil, é um modelo de negócio que surgiu no Brasil em 2012, que também é conhecido como um Shopping Center Virtual. Nele, várias marcas e lojas se reúnem em um único lugar, facilitando para o consumidor a procura pelo melhor produto e melhor preço. Disponível em: < https://www.ecommercebrasil.com.br/artigos/marketplace-vantagens-e-desvantagens/> Acesso em 26 de maio de 2021.

2 O Amazon Prime, é uma assinatura mensal que dá benefícios como frete grátis para produtos selecionados, streaming de música e filmes, acesso a promoções exclusivas, https://www.amazon.com.br/prime?tag=hydrbrgk-

https: $: /$ www. amazon.. com. br/prime?tag=hydrbrgk-
20\&hvadid=381695701607\& hvpos $=\&$ hvexid=\&hvnetw=g\&hvrand $=206890272849040692$ 1 \&hvpone $=\&$ hvptwo $=\& h v q m t=e \& h v d e v=c \& h v d v c m d l=\& h v l o c i n t=\&$ hvlocphy $=20102 \&$ hvtar gid=kwd-342241812160\&ref=pd_sl_2ffjse5d68_e> Acesso em 26 de maio de 2021.

3 Country Manager da Amazon no Brasil

${ }^{4}$ Organizações das Nações Unidas (ONU), é uma organização intergovernamental criada em 1945 para promover a cooperação internacional.
} 
disse o autor Jonah Stillman em entrevista para a Times, ou seja, está inserida na realidade digital desde o nascimento.

Seria natural que, livros digitais tivessem um grande apelo para essa geração, já que são tão inseridos dentro deste mundo desde muito cedo. Entretanto diversas pesquisas mostram exatamente o contrário. O estudo realizado pela empresa Voxburner ${ }^{5}$ em 2013 , mostra que $62 \%$ das pessoas com idades entre 16 e 24 anos, ou seja, nascidas entre os anos de 1989 e 1997, preferiam ler livros impressos. No livro Words Onscreen: The Fate of Reading in a Digital World, a autora e linguista Naomi S. Baron detalha todos os dados coletados por ela durante suas pesquisas, que concluem que leitores jovens preferem livros impressos aos digitais. Em 2019, a empresa Nielsen ${ }^{6}$ divulgou que $63 \%$ de todos os livros impressos comprados no Reino Unidos são para pessoas com idades abaixo de 44 anos.

Compreender o comportamento do consumidor é algo difícil e complexo, principalmente quando tratamos de consumidores jovens. Entretanto, a compreensão das características e comportamentos desses consumidores, que determinam o modo de consumo deles é extremamente importante para que as empresas planejem e implementem estratégias, segundo Larentis (2012).

Pretende-se averiguar as razões que levam esses consumidores a consumir livros físicos, da categoria de romances especificamente, e qual o comportamento e motivação deles em compras realizadas através do ecommerce da Amazon.

\subsection{Objetivo do Estudo}

O comércio eletrônico, vem crescendo muito nos últimos anos. Devido a pandemia do Corona Vírus, no ano de 2020 e 2021, conseguimos perceber um aumento bastante acentuado desse canal de vendas.

A Amazon, por ser um grande nome do comércio eletrônico mundial, vem crescendo e ganhando espaço da mesma forma, tanto com relação a expansão de suas atividades por diversos países, quanto pelo aumento do faturamento da empresa. Livros são um dos produtos mais vendidos pela empresa.

\footnotetext{
${ }^{5}$ A Voxburner é uma empresa de consultoria de marketing estratégico para um público mais jovem, com idades entre 16 e 24 anos. Disponível em: <https://www.voxburner.com/aboutus> Acesso em 26 de maio de 2021.

${ }^{6}$ A Nielsen Media Research é uma empresa global de informação, dados e medição, que oferece uma variedade de informações em pesquisas de mercado usando metodologias próprias. Disponível em: <https://www.nielsen.com/br/pt/about-us/> Acesso em 26 de maio de 2021.
} 
Logo, o objetivo desse estudo é: entender o comportamento de compra e identificar os principais motivos que levam consumidores da geração $Z$ da cidade do Rio de Janeiro a comprar livros físicos de romance no e-commerce da Amazon.

\subsection{Objetivos Intermediários do Estudo}

Para se atingir o objetivo final proposto neste estudo, os objetivos intermediários a serem alcançados são os seguintes:

- Entender quais as motivações do público da geração $Z$ na compra de livros físicos e porque o fazem através de marketplaces digitais.

- Entender quais as motivações para a compra de livros através da Amazon.

- Entender em que momentos o público da geração $Z$ está disposto a consumir através do comércio eletrônico.

- Compreender como se comporta um consumidor da geração Z em compras realizadas no ambiente online, especificamente na Amazon.

- Entender quais são os principais inibidores das compras de livros físicos através de canais digitais para os consumidores da geração $Z$.

\subsection{Foco e Delimitação}

Para esse estudo serão entrevistadas pessoas da geração Z, nascidas entre os anos de 1990 e 2010, da cidade do Rio de Janeiro, que fizeram pelo menos uma compra de livro físico da categoria de romance no último ano, no período de fevereiro de 2020 e fevereiro de 2021.

\subsection{Relevância}

Tal estudo possui relevância para as empresas do setor de livros e marketplaces, pois essas possuem interesse econômico e produtivo na adaptação dos processos, já que com a pandemia do Corona Vírus, houve uma mudança comportamental por parte dos clientes. Para tais empresas é importante que entendam, da perspectiva do consumidor como se deu essa adaptação à nova realidade, e como podem então fidelizar o mesmo para que se mantenham leais a determinada marca ou loja.

Além disso, o estudo possui relevância para acadêmicos, já que nele dados ainda bastante recentes relacionados às tendências no comportamento 
do consumidor durante a pandemia serão integrados com dados e pesquisas de mercado. 


\section{Referencial Teórico}

\subsection{Comportamento do Consumidor}

De acordo com Giglio (2005, p.1) o interesse pelo estudo do consumidor não é algo novo. Desde que se tem registro de relações de troca, já se criavam hipóteses e explicações sobre o comportamento dos consumidores.

Logo, o estudo do comportamento do consumidor tenta entender o que eles compram, por que compram, quando compram, onde compram, com que frequência compram e com que frequência usam o que compram (Schiffman; Kanuk, 2000).

O comportamento do consumidor é definido por Kotler e Keller (2012, p. 164) da seguinte maneira:

O comportamento do consumidor é o estudo de como indivíduos, grupos e organizações selecionam, compram, usam e descartam bens, serviços, ideias ou experiências para satisfazer suas necessidades e desejos.

O comportamento de compra, segundo Kotler e Keller (2012), pode ser influenciado por diversos fatores, entretanto os que exercem maior influência sobre o consumidor são os fatores culturais, sociais e pessoais.

Segundo os autores, o fator cultural é o que exerce maior influência sobre a pessoa e é o principal determinante dos desejos e do comportamento de uma pessoa. Esse tem relação com a cultura em que o consumidor foi criado e exposto.

Já os fatores sociais, também segundo Kotler e Keller (2012) são os grupos de referência, que são aqueles que exercem alguma influência direta ou indireta sobre as atitudes ou comportamentos de uma pessoa, família, que é a mais importante organização de compra de produtos de consumo na sociedade, e os papéis sociais e status da pessoa estudada, que nada mais é do que a posição de uma pessoa em cada grupo.

Quanto aos fatores pessoais, como idade e estágio no ciclo de vida, ocupação e circunstâncias econômicas, personalidade e autoimagem, estilo de vida e valores, o impacto sobre o comportamento do consumidor é direto, segundo Kotler e Keller (2012), e por isso é importante que os profissionais de marketing as conheçam bem. 
Compreender os consumidores traz uma série de benefícios, segundo Mowen e Minor (2003). Entre todos os benefícios, destaca-se o auxílio à gerência na tomada de decisão.

\subsubsection{Comportamento do Consumidor de Literatura no Brasil}

Na quinta edição da pesquisa Retratos da Leitura no Brasil, realizada pelo Instituto Pró-Livro ${ }^{7}$, Itaú Cultural ${ }^{8}$ e IBOPE Inteligência ${ }^{9}$ em 2019, ficou determinado que cerca de há no Brasil cerca de 100 milhões de leitores, que compõem $52 \%$ da população do país.

$\mathrm{Na}$ pesquisa são considerados leitores aqueles que leram, inteiro ou em partes pelo menos um livro nos últimos três meses anteriores à pesquisa.

Destes considerados leitores, $82 \%$ declararam que gostariam de ler mais e a maior causa para a não-leitura entre esses foi a falta de tempo (47\%). Entre os não leitores, os principais fatores para a não-leitura foram a falta de tempo (34\%) e o fato de não gostarem de ler (28\%).

Entre os leitores entrevistados, os dois principais usos do tempo livre são assistindo televisão e usando a internet. É interessante observar como, com o passar dos anos, o uso da internet foi crescendo entre os entrevistados.

7 O Instituto Pró-Livro é uma Organização da Sociedade Civil de Interesse Público, sem fins lucrativos, que tem como objetivo promover pesquisas e ações de fomento à leitura. Disponível em: < https://www.prolivro.org.br/> Acesso em 26 de maio de 2021.

8 O Instituto Itaú Cultural, tem por objetivo o mapeamento de manifestações artísticas e incentivo a pesquisa e a produção artísticas e teóricas relacionadas à diferentes segmentos culturais. Disponível em: < http://www.itaucultural.org.br/> Acesso em 26 de maio de 2021.

9 Extinta em janeiro de 2021, o IBOPE Inteligência fazia pesquisas de opiniões, como as que são realizadas durante as eleições. A marca IBOPE foi vendida para a empresa inglesa Kantar em novembro de 2014 e o ano de 2021 marcou o fim do direito de licenciamento da marca, que passará a pertencer totalmente à companhia inglesa. Disponível em: <https://www1.folha.uol.com.br/mercado/2021/01/ibope-inteligencia-quefaz-pesquisas-de-opiniao-ira-fechar-no-fim-de-janeiro.shtml> Acesso em 26 de maio de 2021 


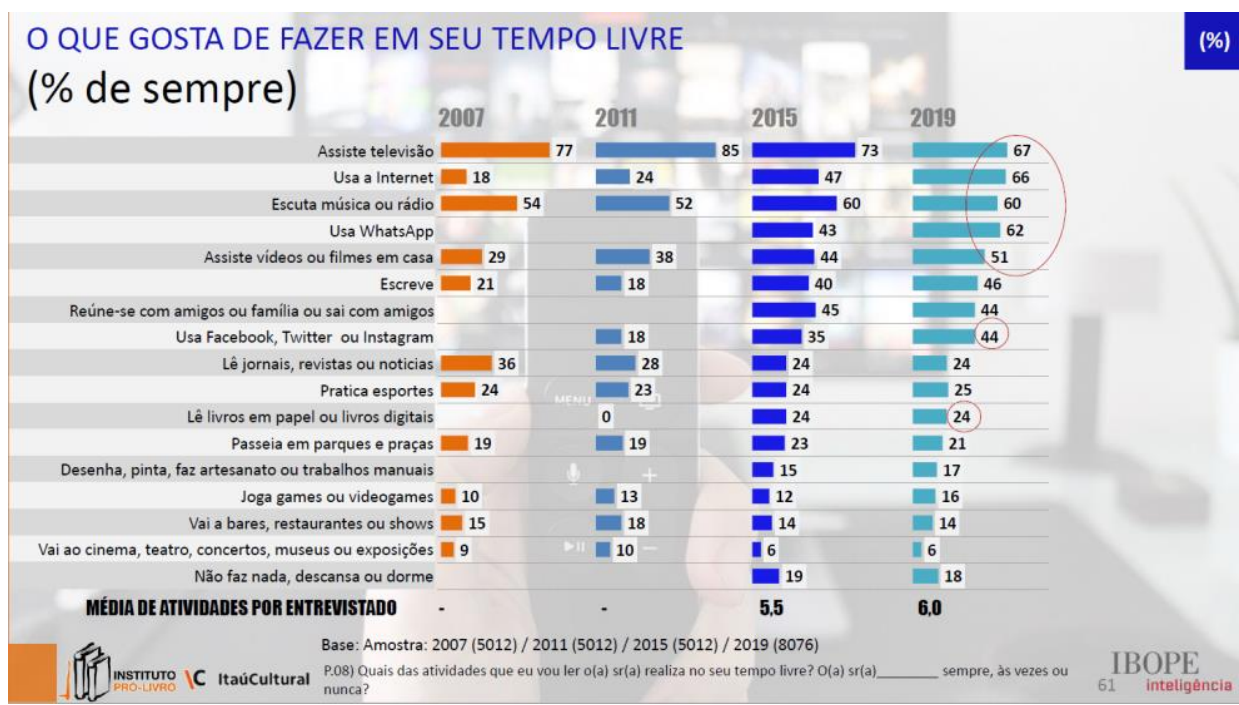

Figura 1: Dados sobre o uso do tempo livre de leitores.

FONTE: $5^{\underline{a}}$ edição da pesquisa Retratos da Leitura no Brasil

A pesquisa também mostrou que cerca de $67 \%$ dos entrevistados preferem o formato físico dos livros para suas leituras.

FORMATO

que prefere ler
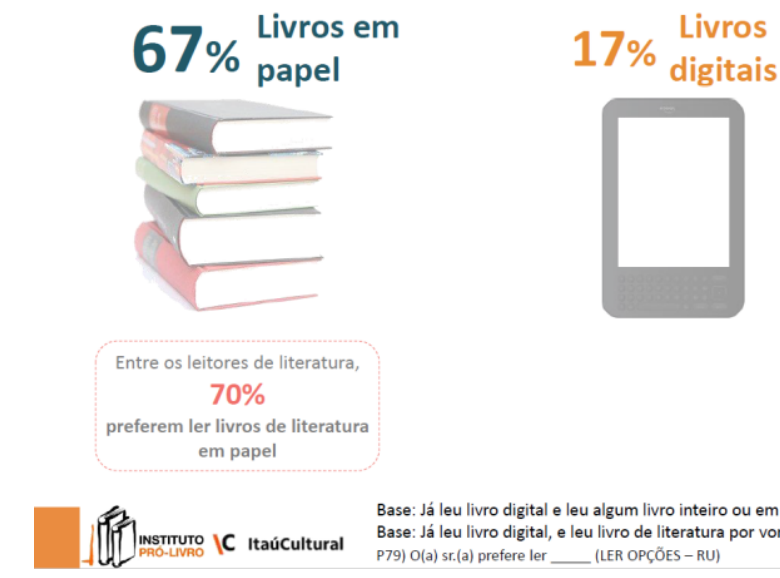

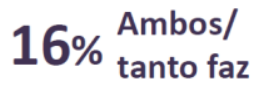

Base: Já leu livro digital e leu algum livro inteiro ou em partes nos últimos 3 meses (1242) Base: Já leu livro digital, e leu livro de literatura por vontade própria (772)

IBOPE P79) O(a) sr.(a) prefere ler___ (LER OPÇC̄ES - RU)

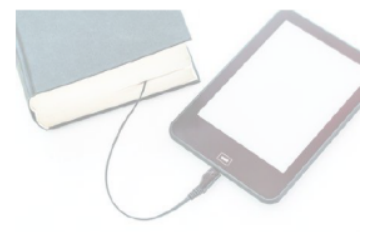

Figura 2: Preferência de formato entre os leitores

FONTE: $5^{\text {a }}$ edição da pesquisa Retratos da Leitura no Brasil

Quanto ao modo de acesso do último livro, 36\% das pessoas afirmam ter adquirido os títulos através de lojas, sendo $9 \%$ desses em lojas online. O formato desde último livro para $92 \%$ dos entrevistados é o físico. 


$$
2019
$$

Último livro que leu ou está lendo foi.

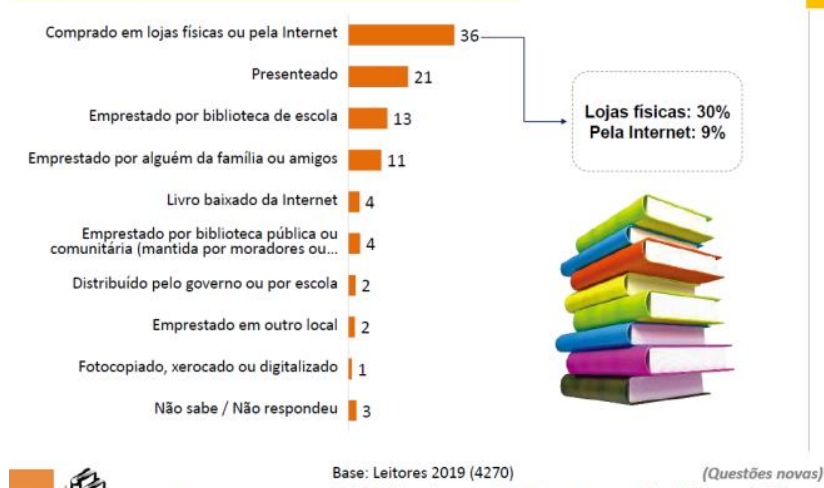

Base: Leitores 2019 (4270)

(Questốes novas)

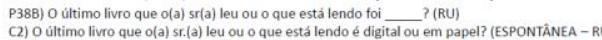

Formato do último livro que leu ou está lendo
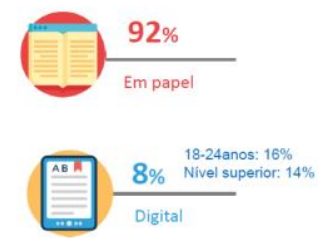

Não sabe / Não respondeu

$\underset{88}{\text { IBOPE }}$

Figura 3: Modo de aquisição e formato do último livro dos leitores entrevistados

FONTE: $5^{\text {a }}$ edição da pesquisa Retratos da Leitura no Brasil

A partir de março de 2020, com a ampla disseminação da pandemia do coronavírus, os consumidores passaram a buscar nos livros uma opção de entretenimento viável durante $\mathrm{o}$ isolamento social, conforme mostram os dados abaixo do estudo realizado pela Nielsen para o Painel de Varejo e Livros no Brasil e divulgado pelo Sindicato Nacional dos Editores de Livros ${ }^{10}$.

Quando comparados, os dados obtidos em fevereiro de 2020 e os obtidos no mesmo período do ano de 2021 , mostram um aumento de $6,29 \%$ no faturamento com vendas de livros. O número de exemplares vendidos cresceu em $18,69 \%$ e o preço médio caiu $10,45 \%$, ficando em cerca de $R \$ 45,65$.

A quantidade de títulos lançados também aumentou 12,59\% entre 2020 e 2021, mostrando assim um mercado editorial aquecido. O estudo também mostra que a importância dos livros de ficção no faturamento das editoras em 2020 foi de $16,73 \%$ e $20,37 \%$ no ano de 2021 e que esses possuem um valor médio de $R \$ 36,62$ no ano de 2021 , tendo uma queda de 4,69\% em comparação com o ano anterior.

10 O Sindicato Nacional dos Editores de Livros, que foi criado em 1941, tem finalidade o estudo e a coordenação das atividades editoriais, bem como a proteção e a representação legal da categoria de editores de livros e publicações culturais em todo o Brasil. Disponível em: < https://snel.org.br/ > Acesso em 26 de maio de 2021 


\subsubsection{Comportamento do Consumidor Virtual}

Com o advento da internet e dos métodos de compra online, houve uma mudança na relação consumidor-vendedor, já que houve um grande aumento no número de opções de escolha e informações disponíveis para que os clientes fizessem suas escolhas.

De acordo com Clarke e Flaherty (2005), a Internet é uma ferramenta poderosa que alterou a maneira de conduzir negócios, proporcionando às empresas e aos consumidores ilimitadas opções e oportunidades.

Com as empresas entrando nesse novo canal de compra houve então o surgimento do consumidor virtual. Este é aquele que utiliza a internet para comprar produtos e serviços.

Segundo Gao (2005), esse consumidor possui diversos benefícios a seu favor quando utiliza essa tecnologia, como a busca global por produtos e serviços, comparação rápida entre as opções disponíveis, facilidade de encontro de informações adicionais sobre o produto, e leitura de opiniões de outros usuários que já efetuaram a compra de determinado produto ou serviço.

Para os consumidores de canais eletrônicos, segundo pesquisa realizada em 2017 pelo SPC Brasil ${ }^{11}$ e pela Confederação Nacional de Dirigentes Lojistas $^{12}$, a familiaridade e confiança estão entro os principais fatores que determinam a escolha dos sites/aplicativos utilizados para a realização das compras. Dos entrevistados $56 \%$ dão preferência à sites/aplicativos em que já tem o costume de realizar comprar e $49 \%$ dão preferência para sites/aplicativos de lojas e marcas conhecidas.

Após a confiabilidade, o preço passa a ser um grande fator na escolha dos sites/aplicativos, já que $37 \%$ dos entrevistados afirmam que após pesquisa de preço, comparam os valores encontrados e escolhem aquele que possui o menor valor.

11 A SPC Brasil é uma empresa de tecnologia vinculada à Confederação de Dirigentes Lojistas para processar e armazenar todas as operações de crédito realizadas pelas empresas. Disponível em: < https://www.spcbrasil.org.br/ > Acesso em 26 de maio de 2021.

12 A Confederação Nacional de Dirigentes Lojistas é uma entidade de classe de nível nacional que tem como objetivo representar o segmento de empresários lojistas nacionalmente. Disponível em: < https://site.cndl.org.br/institucional/historico/> Acesso em 26 de maio de 2021. 
COMO ESCOLHE OS SITES/APLICATIVOS UTILIZADOS

NAS COMPRAS PELA INTERNET (RM)*

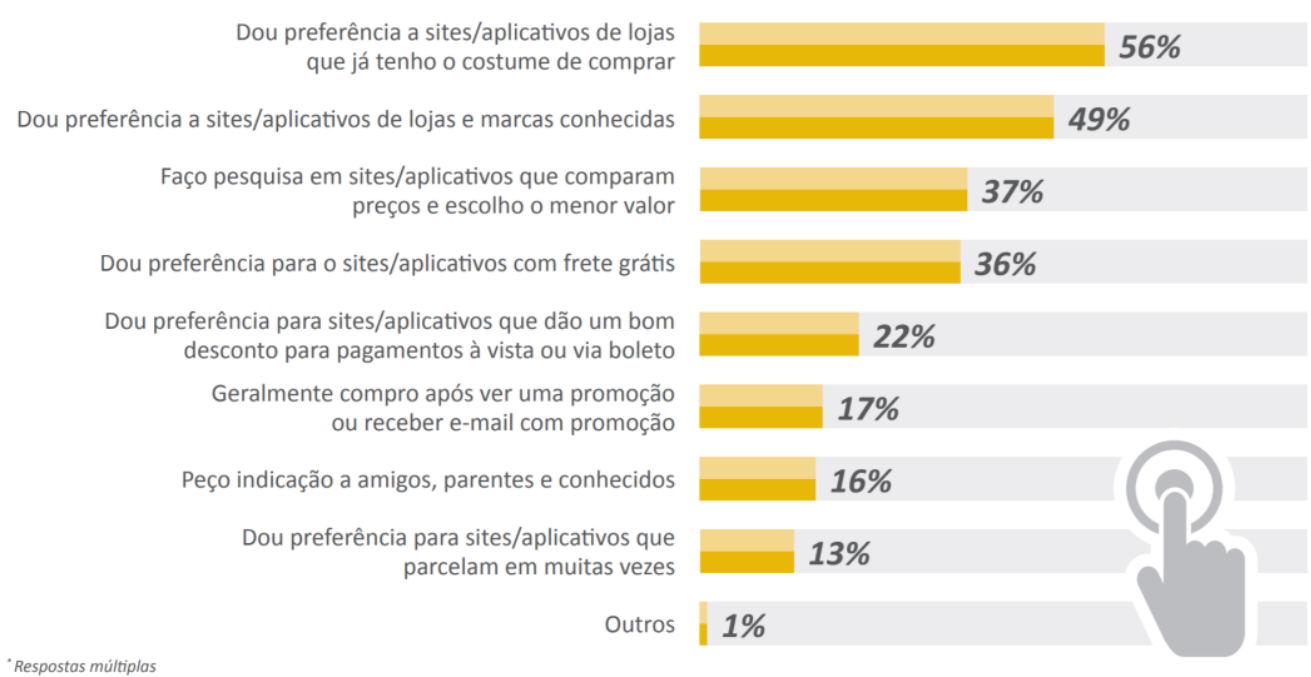

Figura 4: Resultados sobre a escolha de sites e aplicativos utilizados nas compras pela internet.

FONTE: Pesquisa realizada pelo SPC Brasil e pela Confederação Nacional de Dirigentes Lojistas (CNDL).

A mesma pesquisa também mostra que o segundo produto mais comprado de forma não planejada, ou seja, de forma impulsiva pelos entrevistados são os livros (24\%). Eles estão abaixo apenas de itens de vestuário, calçados e acessórios (30\%). 


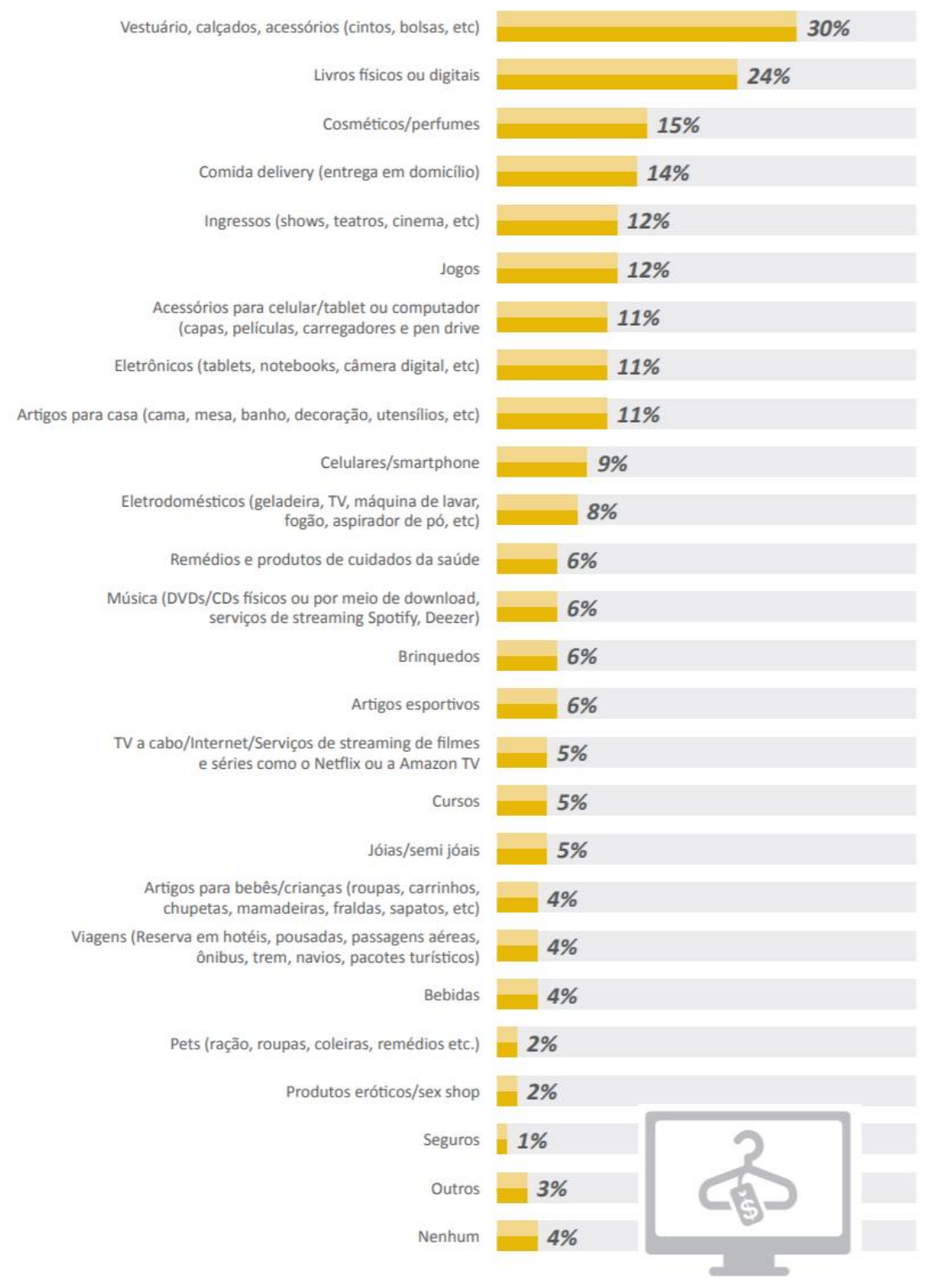

Figura 5: Pesquisa com produtos comprados de forma não planejada.

FONTE: Pesquisa realizada pelo SPC Brasil e pela Confederação Nacional de Dirigentes Lojistas (CNDL).

Em pesquisa realizada pela empresa $A d y e n^{13}$, com 2.000 brasileiros, foi exposto o dado de que, para $86 \%$ deles a facilidade na navegação dos sites é tão importante quanto a qualidade do produto para compras online. Essa porcentagem está acima da média global encontrada, que foi de $72 \%$.

13 Adyen é uma empresa de pagamentos holandesa. Ela permite que as empresas aceitem pagamentos por e-commerce, celular e pontos de vendas. Disponível em: < https://www.adyen.com/pt_BR/ > Acesso em 26 de maio de 2021. 


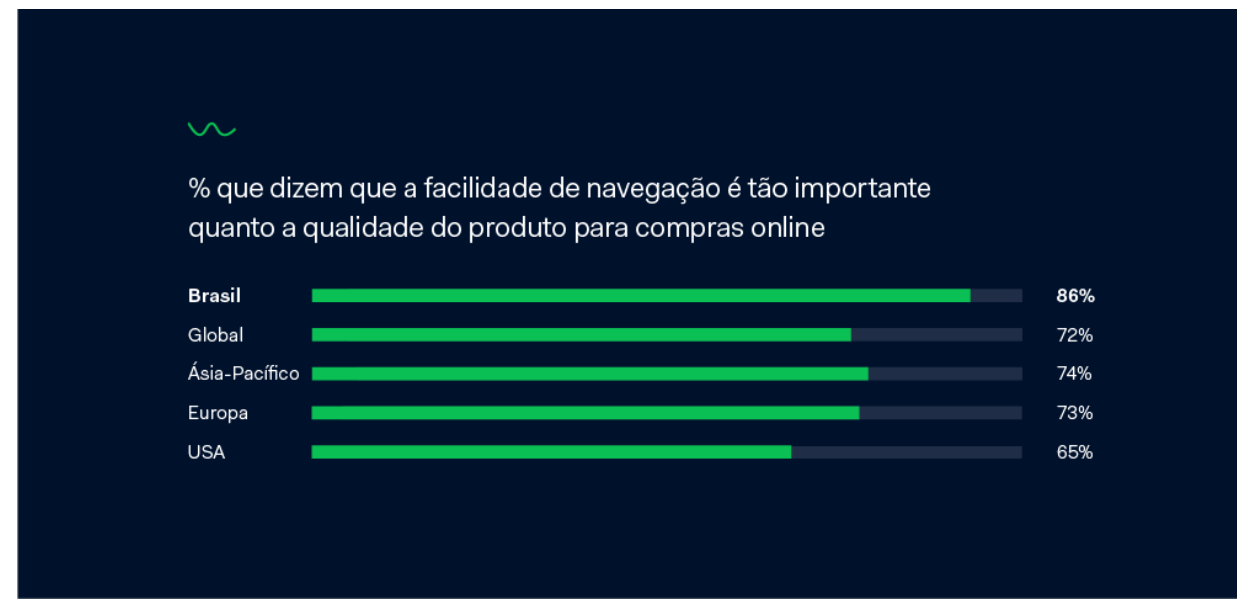

Figura 6: Pesquisa sobre importância da facilidade na navegação em sites de compras.

FONTE: Relatório de Varejo 2021, feito pela empresa Adyen.

\subsubsection{Comportamento do Consumidor no ambiente digital durante a Pandemia do Corona Vírus}

Em artigo escrito para o portal americano Inc. ${ }^{14}$, a empreendedora Maria Haggerty, CEO da Dotcom Distribuition ${ }^{15}$ destacou quatro formas com que a COVID-19 impactou o comportamento de consumo das pessoas no ambiente digital.

O primeiro ponto destacado é o fato de que as pessoas tiveram que se adaptar ao "novo normal". Houve um grande aumento das compras online, e para muitos isso foi um catalizador para a adoção do canal como um meio para as compras.

Segundo dados da pesquisa realizada pela Dotcom Distribution em abril com compradores de canais online americanos, $31 \%$ das pessoas entrevistadas acreditam que farão mais compras online mesmo após o fim da pandemia.

O segundo ponto levantado no artigo pela CEO é que, segundo o estudo State of Commerce Experience, da Bloomreach ${ }^{16}, 50 \%$ dos consumidores estão

\footnotetext{
${ }^{14}$ A Inc. é uma empresa americana de mídia empresarial fundada em 1979 e com sede na cidade de Nova lorque. Disponível em: < https://www.inc.com/ > Acesso em $26 \mathrm{de}$ maio de 2021.

${ }^{15}$ A Dotcom Distribuition é um provedor norte americano de atendimento de pedidos para marcas de comércio eletrônico, B2B e multicanal. Disponível em: < https://dotcomdist.com/about/ > Acesso em 26 de maio de 2021.

16 A Bloomreach é uma empresa que cria soluções exclusivamente para atender profissionais do marketing e comércio digital, com a intenção de ter rápidos crescimentos de receita para seus clientes. Disponível em: < https://www.bloomreach.com/en/about/our-story > Acesso em 26 de maio de 2021.
} 
comprando em comércios eletrônicos produtos que nunca compraram através deste canal antes.

Por estarem comprando mais online e interagindo mais com diferentes empresas, seus padrões para a avaliação da qualidade dos produtos e serviços cresceu. Atualmente, os clientes em uma expectativa de experiências únicas, que se destaquem com relação a todas as suas outras experiências online.

Este mesmo estudo mostrou que $53 \%$ dos entrevistados não fariam uma outra compra em loja depois de terem uma experiência negativa na mesma. Esses fatores mostram como é importante que as lojas e marcas entendam seus consumidores e suas expectativas, de modo a satisfazê-las e assim fidelizar os clientes.

O terceiro ponto é o fato de que os clientes atualmente buscam mais transparência e uma melhor comunicação com a empresa no processo de entrega dos produtos adquiridos por meio de comércios eletrônicos.

O motivo para isto ocorrer é que com o aumento das compras através de canais eletrônicos e o aumento do volume de entregas a serem feitas, os consumidores rapidamente perceberam que os prazos de entrega estendidos eram, diversas vezes, inevitáveis. Consequentemente, foi despertando neles esse novo apetite por uma comunicação melhor, principalmente com relação ao status do pedido e prazo de entrega. Segundo a autora, essa é uma ótima oportunidade para as marcas demonstrarem seu valor e compromisso para com seus clientes.

O quarto e último ponto é a mudança das categorias de produtos mais comprados pelos clientes. Antes da pandemia, segundo uma pesquisa realizada pela Dotcom, as cinco categorias mais compradas através de e-commerces de acordo com os entrevistados eram: itens de vestuário, eletrônicos, utensílios domésticos, acessórios e comidas e bebidas.

No primeiro momento de pandemia, itens essenciais como papel higiênico, álcool em gel e lenços desinfetantes passaram a ser os mais procurados. Essas foram compras, segundo a autora, baseadas no pânico inicial instaurado após o avanço desenfreado da doença.

Entretanto, em meados de abril de 2020, quando o medo inicial diminuiu, a procura por itens como utensílios de cozinha, livros, brinquedos e jogos, artesanatos, equipamentos de exercícios e jardinagem cresceram. Todos os itens citados têm relação com atividades que as pessoas adotaram na vida na quarentena. 
Segundo a empreendedora, segundo a Federação Nacional do Varejo americana, os consumidores estão voltando para as lojas, conforme há o afrouxamento da quarentena. Entretanto, ainda é difícil afirmar se esses padrões serão mantidos.

A atenção e gastos dos consumidores foram direcionados para canais digitais durante o período de isolamento social. Isso representou para as empresas varejistas e marcas uma grande oportunidade na captura e fidelização de clientes abertos à exploração de novas e diferentes opções, fazendo desse um momento propício para o investimento em ferramentas que ajudem as empresas a entender seus clientes. Dessa forma, elas conseguirão se posicionar melhor para conduzir avaliações e garantir a lealdade dos consumidores.

No Brasil, segundo a empresa Adyen, por conta das medidas restritivas impostas, estima-se que cerca de 5,7 milhões de consumidores entraram no mercado digital entre os meses de abril e junho de 2020.

No Relatório de Varejo divulgado pela empresa em fevereiro de 2021, é exposto o fato de que $63 \%$ dos brasileiros passaram a consumir através de aplicativos para pedidos e compras. Um valor muito superior ao que foi encontrado para a média global, que foi de $33 \%$.

\subsubsection{Expectativa para o Comportamento do Consumidor no ambiente digital após a Pandemia do Corona Vírus}

Em seu Relatório de Varejo de 2021, a empresa Adyen listou quais mudanças no comportamento do consumidor do país a mesma acredita que não mudarão após o fim da pandemia do Covid-19.

A empresa mostra no documento que, durante o período, o cliente passou a dar mais valor para as experiências, seja em lojas físicas ou digitais. Dos entrevistados, 68\% afirmam que as lojas devem ter uma estética e layout mais atraente e $90 \%$ afirmam que não comprarão em locais onde tiveram experiências ruins, seja no online ou offline.

No cenário pós pandêmico, $91 \%$ dos brasileiros afirmam que é importante que a flexibilidade que foi apresentada durante o isolamento social, ou seja, as vendas em novos canais e prazos de entrega rápidos, continue.

O relatório também mostra que, para os consumidores, cada vez menos as barreiras entre os ambientes físicos e digitais fazem sentido. Logo, como legado fica a maior integração entre os ambientes. 
Quanto à fidelização, o estudo mostra que os brasileiros estão cada vez mais engajados, e mostram se importar cada vez mais com a parte ética das marcas. Estão dispostos a alterar comportamentos de rotina para que possam consumir de empresas com práticas alinhadas com seus pensamentos éticos e passaram a consumir mais em negócios locais para ajudá-los a continuar abertos.

O estudo também mostra que $45 \%$ das pessoas estão menos dispostas a comprar em lojas físicas após a experiência da compra online.

Dos consumidores brasileiros entrevistados, 62\% acreditam que farão mais compras online do que faziam antes da pandemia. Esse valor está acima da média mundial encontrada na pesquisa, que foi de $36 \%$.

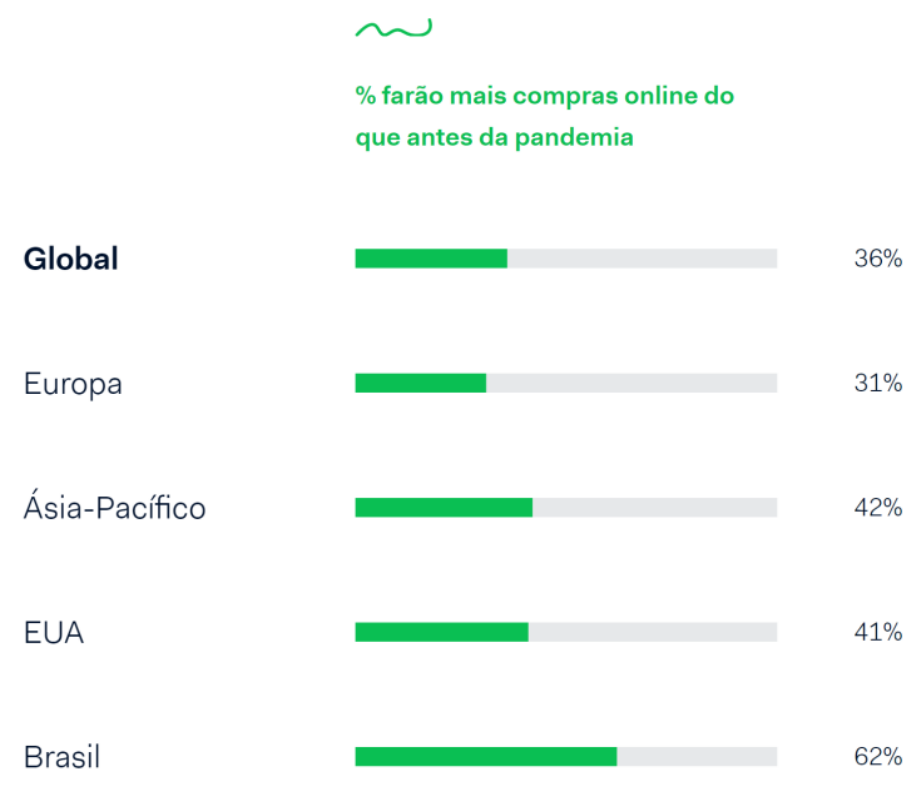

Figura 7: Pesquisa sobre comportamento de compra no cenário pós pandêmico.

FONTE: Relatório de Varejo 2021, feito pela empresa Adyen

\subsubsection{Impacto da Amazon no Comportamento de Compra}

A Amazon, que surgiu em 1995, é conhecida atualmente como a maior companhia de comércio eletrônico do mundo. A empresa, que chegou no Brasil em 2012, é um dos principais nomes do mercado digital, tendo no ano de 2020 um faturamento US $\$ 386$ bilhões.

A empresa, além de revolucionar o mercado através de ideias disruptivas para o mercado de varejo, também influenciou e continua influenciando no comportamento de compra das pessoas. De acordo com a pesquisa realizada 
pela $\mathrm{PwC}^{17}$ em 2017, em média, 28\% das pessoas do mundo afirmam que tiveram seu comportamento de compra influenciado pela empresa, ou seja, afirmam que compram menos em lojas físicas devido a empresa Amazon. No Brasil, essa porcentagem cresce para $35 \%$.

Na pesquisa, também é possível ver que $34 \%$ dos brasileiros iniciam suas pesquisas por produtos no site da companhia de Jeff Bezos e 54\% verificam os preços no site quando querem realizar uma compra. Outro dado importante levantado no estudo é o de que $47 \%$ dos entrevistados já realizaram pelo menos uma compra no site, o que é um valor abaixo da média mundial de $56 \%$. Isso pode ser um reflexo do fato de que o portfólio da empresa no Brasil é consideravelmente menor do que em outros países, já que a operação no país é mais recente.

Segundo entrevista dada por Alex Szapiro para a CNN Brasil Business, o Brasil foi o que mais cresceu no mundo em termos de assinaturas, nos primeiros 15 meses de funcionamento.

Durante a mesma entrevista o executivo afirma que a intenção da empresa é gerar "um valor desproporcional ao que o cliente paga com relação aquilo que ele recebe", agregando assim mais valor às assinaturas oferecidas para seus clientes.

\subsection{Geração Z}

A Geração Z, segundo definição de Goliath (2006), são as pessoas nascidas entre 1990 e 2010, em países tecnologicamente avançados e aderentes à revolução digital ocorrida no começo desta mesma década. Aqueles nascidos nesse período nunca viveram em um mundo sem computadores, celulares e chats. Por esse motivo, sua forma de pensar foi influenciada, desde muito cedo, por um mundo complexo e rápido que a tecnologia criou.

Uma das características mais marcantes daqueles que pertencem a essa geração é a rapidez com que conseguem informações e a fácil irritabilidade quando essas não chegam a eles rapidamente. Outra característica importante dessa geração é o poder que tem de prestar atenção em diversas coisas ao mesmo tempo.

17 A PwC, antes conhecida como PricewaterhouseCoopers é uma empresa de consultoria e auditoria, fundada em 1998 e com sede em Londres, Inglaterra. Disponível em: < https://www.pwc.com.br/pt/quem-somos.html > Acesso em 26 de maio de 2021. 
De acordo com Goliath (2006), aqueles que pertencem a Geração Z foram os primeiros a nascer em um mundo totalmente digital, e por esse motivo se tornaram uma geração muito bem conectada. Esses aprenderam a conviver bem com equipamentos tecnológicos e tiveram a sua disposição serviços e aplicativos como navegadores web, mensagens instantâneas, banda larga e conexão sem fio.

Por terem nascido nesse cenário globalizado bastante consolidado, essa geração se mostra mais exigente e inquieta e assim, começam a desenvolver um novo perfil do consumidor, que combina características da Geração Y com preocupações em relação à sustentabilidade. Além disso, não se mostram dispostos a pagar por produtos que conseguem encontrar de forma gratuita na internet (FEGHALI; DWYER, 2004).

É importante ressaltar que há diferentes definições para a Geração Z na literatura. Para alguns autores, como Levy e Weitz (2000), fazem parte dessa geração aqueles que nasceram entre os anos de 1989 e 2010. Há também quem defina os membros dessa geração como aqueles que nasceram entre os anos de 1995 até os dias atuais. Essa definição é utilizada em diversas pesquisas, como a realizada pela empresa Criteo e a realizada pela empresa Rakuten Digital Commerce.

Para esse estudo, como dito anteriormente, será considerado como geração Z aqueles que nasceram a partir do ano de 1990 até o ano de 2010.

\subsubsection{Comportamento de Compra da Geração Z no ambiente online}

Em pesquisa feita pela Criteo, e divulgada no Relatório sobre a Geração Z, vimos que $65 \%$ das pessoas dessa geração não gostam de comprar novos itens se não podem vê-los nem os tocar em uma loja física.

Além disso, $80 \%$ dos membros dessa geração gostam de comprar nas lojas físicas quando tem tempo para isso. Isso mostra que esse público aprecia o varejo da forma mais tradicional para que possam experienciar os produtos, e descobri-los antes da compra.

Entretanto, no relatório também há o dado de que $75 \%$ dos membros dessa geração preferem comprar online o máximo possível e, dentro das lojas físicas, $67 \%$ deles usam seus smartphones para pesquisar o que pretendem comprar.

Desses jovens, $18 \%$ fazem o que é chamado de Showrooming, isto é, conferem o produto nas lojas físicas, mas o compram online. 
Para os jovens dessa geração, o que mais os atrai a fazer compras em e-commerces segundo o relatório são os descontos disponíveis (62\%), seguido então por devolução com frete grátis (58\%).

É importante destacar que a definição de geração $Z$ feita pela pesquisa da Criteo é diferente da definição que este estudo tem. Na pesquisa feita pela empresa, consideram geração Z aqueles que nascem depois de 1994 até os dias atuais, ou seja, pessoas nascidas entre 1990 e 1994 serão consideradas neste estudo, mas não foram consideradas nesses dados acima apresentados.

Em pesquisa realizada pela Rakuten Digital Commerce em 2017, onde forma considerados como geração $Z$ pessoas que nasceram a partir de 1995 , podemos notar que $22 \%$ da geração $Z$ faz compras por impulso no ambiente online. Além disso, para eles a economia (43\%) e a rapidez (30\%) são os dois fatores que mais valorizam na compra online.

Uma curiosidade apresentada no estudo é que as pessoas da geração $Z$ (41\%) que declaram ter comprado livros é duas vezes maior do que os da geração $Y(20 \%)$. Além disso, essa é a geração que menos desiste das suas compras, com um percentual de $56 \%$. 


\section{Metodologia}

Ao longo deste capítulo serão apresentados os estágios que demonstram os procedimentos de etapas de coleta de dados; as fontes de informações selecionadas para a coleta; os procedimentos e instrumentos de coleta usados no estudo e as limitações dele.

\subsection{Etapas de coleta de dados}

Neste estudo foi feita uma pesquisa exploratória qualitativa, que tem como objetivo investigar o comportamento do consumidor da geração Z, moradores da cidade do Rio de Janeiro, na compra de livros físicos de romance na loja online Amazon. Para isso foram realizadas entrevistas com pessoas que se enquadram nessas características e que realizaram a compra dos livros físicos no último ano.

As entrevistas, como dito anteriormente, tem como objetivo analisar o comportamento dos consumidores de livros físicos de romance no e-commerce da Amazon, identificar suas principais características e quais são os principais motivos que os levam a consumir livros físicos através deste marketplace.

\subsection{Fontes de Informações selecionadas para a coleta de dados no estudo}

Durante essa etapa do trabalho, foram selecionadas 23 pessoas pelo critério de amostragem por acessibilidade ou conveniência. Essa é uma técnica comum, e se trata de selecionar pessoas que sejam acessíveis dentro de uma população, segundo definição de Schiffman e Kanuk (2000).

Esse critério é aceito em estudo exploratórios, como este, já que não é exigido um nível de precisão elevado. Os indivíduos, que fazem parte de um grupo ao qual o entrevistador tem acesso, foram escolhidos por se encaixarem no perfil do público-alvo delimitado anteriormente. (Aguiar e Steinhäuser, 2019)

Logo, essa amostragem é do tipo não probabilístico, ou seja, é aquela em que a seleção dos elementos da população para compor a amostra depende ao menos em parte do julgamento do pesquisador ou do entrevistador no campo. (Mattar, 2012). 


\subsection{Procedimentos e instrumentos de coleta de dados utilizados no estudo}

$\mathrm{Na}$ etapa da pesquisa exploratória, onde os dados foram colhidos, foram realizadas entrevistas individuais por vídeo conferência, utilizando a ferramenta ZOOM. Logo, foram realizadas ligações de vídeo com todos os entrevistados, onde as perguntas elaboradas com o objetivo colher os dados necessários para fazer a análise proposta pelo estudo foram feitas aos entrevistados.

A pesquisa, segundo definição de Gil (2002), é o procedimento racional e sistemático que tem como objetivo proporcionar as respostas aos problemas que são propostos.

Devido o fato que o objetivo da pesquisa possui um caráter subjetivo, tal como identificar padrões de comportamento, significados e reações dos entrevistados, uma abordagem qualitativa foi utilizada pela natureza do próprio estudo. (Aguiar e Steinhäuser, 2019)

Logo, cada entrevista foi realizada de forma individual pelo entrevistado, com base em um roteiro de perguntas pré-definido (Anexo 1). Aqueles que foram entrevistados foram questionados sobre o seu comportamento de compra, com o objetivo de analisar esse comportamento, identificar quais são os principais motivos que os levam a consumir livros físicos através do e-commerce da Amazon.

Como essa análise utiliza uma amostra pequena quando comparamos ao todo, podemos dizer que ela o representa de maneira genérica, ou seja, sem um elevado nível de precisão.

\subsection{Limitações do Estudo}

A pesquisa aqui apresentada será feita baseada em dados reais, porém com limitações de assertividade por se tratar de um estudo de amostra não probabilística, fazendo com que os dados não tenham um alto nível de precisão, já que o número de pessoas estudadas é pequeno quando comparado ao todo.

Entretanto, essas contingências não afetam a qualidade do estudo, já que as conclusões obtidas pretendem trazer uma melhor compreensão e visão sobre o assunto aqui tratado, do comportamento do consumidor da geração $Z$ de livros físicos da categoria de Romances do comércio eletrônico Amazon. 


\section{Análise das Respostas}

Neste capítulo os dados e informações coletados através das entrevistas (Anexo 2) realizadas individualmente com pessoas da geração $Z$, que moram no Rio de Janeiro, serão apresentados.

\subsection{Perfil dos Entrevistados}

O grupo de pessoas entrevistadas foi comporto por 23 pessoas, com idades entre 28 e 19 anos, todos pertencentes da geração Z, conforme definição adotada por esse estudo.

Foram identificadas pessoas das classes $A$ e $B$, sendo da primeira 14 pessoas e 9 da segunda. Tal classificação foi feita com base no critério de definição de Classe Social por Faixas de Salário-Mínimo (IBGE). Esse tipo de classificação usa como base a renda familiar sob a perspectiva de saláriosmínimos. A tabela abaixo mostra como é feita a classificação.

Tabela 1: Classificação IBGE

\begin{tabular}{|c|c|}
\hline Classe & Renda Familiar (em salários mínimos) \\
\hline A & Acima de 20 salários mínimos \\
\hline B & De 10 a 20 salários mínimos \\
\hline C & De 4 a 10 salários mínimos \\
\hline D & De 2 a 4 salários mínimos \\
\hline E & Até 2 salários mínimos \\
\hline
\end{tabular}

Fonte: IBGE.

Dos entrevistados 3 são do sexo masculino e 20 do sexo feminino e todos são moradores do Rio de Janeiro. O perfil dos entrevistados pode ser observado na tabela abaixo, onde os nomes dos entrevistados foram ocultados para que fosse mantida sua privacidade. 
Tabela 2: Dados dos Entrevistados

\begin{tabular}{|c|c|c|c|}
\hline Entrevistado & Sexo & Idade & Classe \\
\hline ENTREVISTADO 1 & Feminino & 25 anos & A \\
\hline ENTREVISTADO 2 & Feminino & 21 anos & A \\
\hline ENTREVISTADO 3 & Feminino & 22 anos & A \\
\hline ENTREVISTADO 4 & Feminino & 20 anos & B \\
\hline ENTREVISTADO 5 & Feminino & 25 anos & A \\
\hline ENTREVISTADO 6 & Feminino & 25 anos & B \\
\hline ENTREVISTADO 7 & Feminino & 25 anos & A \\
\hline ENTREVISTADO 8 & Feminino & 28 anos & B \\
\hline ENTREVISTADO 9 & Feminino & 20 anos & A \\
\hline ENTREVISTADO 10 & Feminino & 24 anos & A \\
\hline ENTREVISTADO 11 & Feminino & 20 anos & A \\
\hline ENTREVISTADO 12 & Feminino & 20 anos & B \\
\hline ENTREVISTADO 13 & Feminino & 23 anos & A \\
\hline ENTREVISTADO 14 & Masculino & 21 anos & B \\
\hline ENTREVISTADO 15 & Feminino & 20 anos & A \\
\hline ENTREVISTADO 16 & Feminino & 25 anos & A \\
\hline ENTREVISTADO 17 & Masculino & 21 anos & B \\
\hline ENTREVISTADO 18 & Feminino & 24 anos & B \\
\hline ENTREVISTADO 19 & Feminino & 24 anos & A \\
\hline ENTREVISTADO 20 & Feminino & 24 anos & B \\
\hline ENTREVISTADO 21 & Feminino & 25 anos & A \\
\hline ENTREVISTADO 22 & Masculino & 19 anos & B \\
\hline ENTREVISTADO 23 & Feminino & 22 anos & A \\
\hline
\end{tabular}

Fonte: Feito pela autora (2021).

\subsection{Comportamento do Consumidor da Geração Z na Amazon}

Através da análise das entrevistas feitas, podemos observar que o principal comércio eletrônico utilizado pelos membros da geração $Z$ para a compra de livros é a Amazon.

Durante as entrevistas, todos afirmaram que esse é o principal canal eletrônico onde realizam suas compras literárias. Como justificativa para a escolha, muitos relatam a rápida entrega e o preço bastante competitivo como os principais motivos para tal escolha.

Muito destacado como grandes diferenciais da empresa, e grandes estimuladores para as compras no site são também a qualidade da entrega, ou seja, os produtos chegam em boas condições, a usabilidade da plataforma, descrita por muitos como bastante intuitiva e de simples navegação e a assinatura do Amazon Prime. 
De todos os entrevistados, apenas dois não possuíam o Amazon Prime, que dá aos assinantes o benefício de fretes grátis em compras. Esse é outro grande motivo que leva os usuários a preferirem realizar suas compras na Amazon, já que não contabilizam o frete no preço cheio do produto.

A frequência de compras no marketplace relatada pela grande maioria dos entrevistados é bastante alta. Um entrevistado afirma que faz compras no site semanalmente, e outros dois afirmam fazer quinzenalmente. Além deles, 12 entrevistados afirmam fazer compras mensal ou bimestralmente.

Dos outros 8 entrevistados, 5 relatam ter uma frequência de compras trimestral ou semestral, enquanto os outros três afirmam não ter uma frequência para compras.

Quanto à impulsividade dos membros da geração, apenas 7 afirmaram fazer compras mais de forma impulsiva. Todos os restantes afirmam ter suas compras definidas antes mesmo de entrar no site, apesar de muitas vezes olharem as listas de livros sugeridos.

Já com relação à quantidade de livros que compram, o maior valor relatado foi o de 70 livros comprados no último ano, pela entrevistada 3 , enquanto 0 menor valor foi de 3 livros comprados no último ano, pelo entrevistado 20.

Entretanto, quando perguntados sobre a quantidade de romances, o maior valor foi de 56 livros, resposta do entrevistado 8. Já o menor valor para esse questionamento foi o de 2 livros, na entrevista de número 7. Na Amazon, os valores relatados para a compra de livros físicos de romance variam entre $38 \mathrm{e}$ 1, com o maior valor sendo do entrevistado 22 e o menor do entrevistado 18.

Sobre o formato, 6 afirmam preferir ler no formato digital, enquanto 17 afirmam preferir ler no formato físico.

Como justificativa para a preferência da leitura no formato digital, muitos destacam a praticidade de "gadgets" como um dos principais fatores, como podemos ver no trecho da entrevista número 11 abaixo:

Acho que no Kindle você tem essa facilidade do peso, de ficar mais fácil de você levar para os lugares, então no início do ano passado, quando eu ainda ia para a faculdade, eu levava e ia lendo no metrô, já ia adiantando as minhas leituras. Então eu acho que essa é a questão, a praticidade, parece que você está lendo mais rápido. (Entrevistado 11, 20 anos)

Já com relação aos livros físicos, os benefícios relatados muitas vezes são mais relacionados a sentimentos do que a realmente benefícios do formato, 
como por exemplo, o cheiro de livro, a sensação de passar as páginas e o apego ao livro. Podemos notar isso no depoimento abaixo, do entrevistado 1:

Gosto da sensação de ter o livro na mão, passar as páginas, gosto do cheirinho também de livro novo. É... eu sei que eu leio muito na rua e que o livro digital seria mais prático, por ser mais leve e tal, mas eu não consigo ter a sensação de que eu estou lendo alguma coisa. (Entrevistado 1, 25 anos)

Também, a maioria das pessoas que afirmam preferir o formato físico, relatam o gosto por escrever e marcar os livros, o que não é possível no formato digital.

Já quando perguntados sobre qual era o fator que mais levavam em consideração no momento da compra, o mais levantado foi o preço, com 13 pessoas o citando como o mais relevante. O segundo mais levantado foi o tempo de entrega, com três pessoas o citando e o terceiro foi a história do livro que estão comprando, com duas pessoas o citando. Outros fatores levantados foram a capa do livro, a vontade de ler a história, a praticidade, a confiança na empresa e a confiança na entrega. Cada um deles foi citado por uma pessoa na entrevista.

Apesar de preço ser um fator de grande relevância para grande parte dos entrevistados, muitos afirmam não fazer procuras em outros marketplaces. Muitos confiam que a Amazon possui o melhor preço, além de afirmarem preferir comprar neste CE devido ao frete grátis proporcionado pelo Amazon Prime. "[...] Agora eu tenho Amazon Prime, então normalmente eu vou direto na Amazon mesmo. Se o preço estiver muito alto, aí eu dou uma comparada com outros sites, mas muito raro.", disse o entrevistado 8 quando questionado sobre pesquisas em outros marketplaces.

Outro fator que foi possível observar durante a realização das entrevistas é a preocupação de uma parte dos entrevistados com questões éticas das empresas e preocupação em buscar consumir diretamente de pequenas e médias empresas, como livrarias e editoras, com a intenção de ajuda-las no momento de crise.

Entretanto, destacam a diferença nos preços, muitas vezes grande demais para ser relevada, e a demora na entrega como razões que não os levam a consumir mais em tais canais de compra e passar a então consumir na empresa de Jeff Bezos.

Podemos ver exatamente isso no trecho da entrevista de número 1 abaixo: 
Quando eu tenho que comprar livro online eu geralmente procuro em sites de livrarias menores. Mas nesses lugares geralmente o prazo de entrega é muito longo [...]. Ou não tem o livro em estoque e eles vão comprar pra entregar, [e nesse caso] o prazo de entrega fica de 30 dias. Nesses casos eu geralmente vou para a Amazon. Ou se, por exemplo, tem uma diferença grande de preço de mais de 15 ou 20 reais. (Entrevistado 1, 25 anos)

\subsection{Motivações que levam o consumidor da geração $Z$ a comprar livros físicos online}

Com as entrevistas foi possível verificar que, apesar de já comprarem com certa frequência na Amazon, a pandemia foi um grande catalizador nas compras online dos entrevistados, o que está de acordo com o que foi dito pela CEO da empresa Dotcom Distribuition.

Muitos a citam como um grande motivador para as compras online no ano passado, já que os lockdowns decretados ao longo do ano impunham que as pessoas evitassem circular nas ruas e impediam a abertura de livrarias.

Podemos perceber isso no trecho abaixo, da entrevista de número 14:

Falando assim numa perspectiva geral, todo mundo começou a consumir mais na internet no ano passado. Então eu ia muito em livrarias mesmo e gostava muito de ir nos sebos do centro antes da pandemia. Com a pandemia, eu não pude mais fazer isso... Desde o ano passado eu não faço mais isso. É... comprar pela internet acaba suprindo essa minha "necessidade" de ir atualizando minha estante. (Entrevistado 14, 21 anos)

Outro fator muito levantado foi o do preço dos livros nos e-commerces, que muitas vezes são mais baixos do que aqueles praticados por livrarias e o da praticidade das compras realizadas na internet. Segundo o entrevistado 4, esses são os grandes motivos que o levam a fazer a compra de livros físicos através de canais digitais. "Preço. Com certeza preço. $E$ também é mais cômodo não ter que sair de casa para comprar meu livro." disse ele durante a entrevista.

Além disso, a praticidade das compras online foi muito mencionada, a rapidez com que a compra e a entrega são feitas e a grande disponibilidade de livros para venda nos sites. 


\subsubsection{Motivação para a compra de livros através da Amazon}

Com relação à Amazon, a principal motivação para as compras é o preço. A grande maioria menciona o e-commerce como o local mais barato para a compra de livros novos.

Também, como mencionado anteriormente, a grande maioria dos entrevistados é assinante do Amazon Prime, e entre diversos benefícios, o frete grátis para produtos selecionados é um deles. Isso influencia muito na escolha do site para a realização das compras, além de gerar uma fidelização dos consumidores, que afirmam nem fazerem buscas em outros marketplaces por esse motivo.

Podemos ver como o benefício influencia na decisão de compra do entrevistado 4, além do preço, no seguinte trecho da entrevista: "Para mim [o que influencia na minha escolha da Amazon para a realização das compras é o frete grátis. Porque [...], eu assino o Amazon Prime, então [...] acaba valendo mais a pena. E o preço também.".

Isso também afeta no preço final do produto, fazendo com que os valores, já bastante competitivos, se tornem ainda mais interessantes quando comparados com o dos concorrentes, fazendo com que escolham o site para a realização das compras.

Outro grande fator mencionado é a rapidez e qualidade nas entregas realizadas. Afirmam que os livros sempre chegam em no máximo 3 dias e sem nenhum problema, como páginas amareladas ou muito amassados do transporte. Tais fatores foram mencionados no seguinte trecho da entrevista de número 23: "Para mim é a rapidez da Amazon. Já aconteceu de eu comprar o livro na quarta-feira e na quinta de manhã o livro já ter chegado. [...] E também a qualidade de como o produto chega."

Além disso, como dito anteriormente, muitos elogiaram a funcionalidade do site e app. Afirmam ser fácil de navegar e bastante intuitivo, fazendo com que isso seja um grande diferencial com relação aos concorrentes na venda de livros no Rio de Janeiro. Isso pode ser observado no seguinte fragmento de resposta "Para mim a usabilidade do site e aplicativo da Amazon é muito melhor do que a dos concorrentes" dado pelo entrevistado 7.

Foi possível verificar durante a entrevista que a empresa possui a confiança dos seus compradores. Apesar de alguns relatarem problemas com entregas ou na compra de modo geral, o atendimento ao cliente e a rapidez na resolução dos problemas fazem com que os entrevistados sintam confiança em 
continuar comprando no marketplace, além de influenciar positivamente na escolha de onde farão suas compras.

$\mathrm{Na}$ resposta abaixo, dada pelo entrevistado 10, podemos observar exatamente isso:

Porque assim, a Amazon, qualquer problema que dá, eles entram em contato com você na hora e resolvem o problema [...]. Você não tem dor de cabeça. Isso, para mim, como consumidor é muito importante, porque comprar na internet algumas vezes dá muita dor de cabeça.

\subsection{Inibidores de Compras Online}

Apesar de muitos terem dificuldades de se lembrar de momentos em que cancelaram ou desistiram de compras de livros online, quando questionados 0 que mais foi mencionado como um inibidor das compras foi o preço final da compra.

Muitos afirmaram colocar os livros no carrinho e no momento de fechar a compra "pensam melhor" sobre quais produtos realmente querem ler. Também, para livros, a quantidade que possuem em casa ainda para ler é um grande fator que os levam a pensar melhor sobre os novos que desejam comprar.

Como praticamente todos possuem Amazon Prime e na maioria das vezes não pagam pelo frete, esse fator não entra no cálculo do valor final. Entretanto, alguns afirmam que em outros marketplaces esse é um fator que os leva a desistência da compra.

Podemos notar isso no segmento abaixo, da resposta do entrevistado 12 , quando questionado sobre o que o leva a desistir de uma compra online:

Geralmente o que me faz desistir é tipo, eu vou pensando se eu vou ler agora, se eu realmente quero esse livro... E também tem aquela questão do frete que eu já falei (quando o frete é caro, se igualando algumas vezes ao preço dos livros).

Quando o frete é considerado caro, os usuários da geração Z desistem da compra, mesmo que o valor do produto seja competitivo. Isso pois o valor final da compra é afetado e assim, influencia na decisão de compra deles. 


\section{Conclusões}

O estudo teve como objetivo entender o comportamento de compra e identificar os principais motivos que levam consumidores da geração $Z$, nascidos entre os anos de 1990 e 2010, da cidade do Rio de Janeiro a comprar livros físicos, da categoria de romance, no comércio eletrônico da Amazon. Para o embasamento dele foram feitas revisões da literatura sobre o comportamento do consumidor, mais especificamente do consumidor virtual e do consumidor de livros, a fim de compreender motivações e fatores que influenciam na compra de tais produtos e na escolha dos canais onde farão as compras e sobre a geração $Z$ e seu comportamento de compra no ambiente digital.

Também foram trazidas pesquisas relacionadas à mudança no comportamento do consumidor no cenário pandêmico atual e quais são as expectativas para o futuro pós pandemia, com a intenção de compreender o cenário do varejo digital atual e quais são as projeções para o futuro com relação ao comportamento dos clientes.

Para que a pergunta do estudo fosse respondida, foram realizadas entrevistas semiestruturadas, através de aplicativos de videotelefonia, com uma amostra pré-selecionada de pessoas moradoras da cidade do Rio de Janeiro, com idades entre 28 e 19 anos e que compraram, durante o período de fevereiro de 2020 e fevereiro de 2021, pelo menos um livro através da Amazon.

\subsection{Conclusão final dos estudos sob a perspectiva da pesquisa e entrevistas}

Através dos dados e informações reunidas após a realização das entrevistas foi possível identificar padrões de comportamento dos consumidores da geração $Z$ de livros físicos de romance na Amazon. São jovens que priorizam principalmente o preço durante a tomada de decisão de compra, seguido então pelo prazo de entrega do produto. Esses são os principais motivos que os levam a consumir através de marketplaces digitais.

Além disso, também foi possível observar durante as entrevistas que o isolamento social imposto devido à pandemia mundial do novo Corona Vírus foi um grande motivador para as compras online, principalmente de livros físicos. Muitos relataram que, antes mesmo da pandemia, já realizavam compras através de da gigante do comércio eletrônico, entretanto, em menor frequência e 
comprando menos quantidade de livros. Todavia, quando as livrarias foram impedidas de abrir suas portas e a circulação de pessoas foi desestimulada, a empresa foi um canal importante para que conseguissem suprir a necessidade que tinham por novos livros.

Já com relação à escolha de livros físicos, as entrevistas permitiram que fosse concluído que a compra dos títulos neste formato se dá principalmente devido à fatores sensoriais, como o cheiro do livro e a sensação das páginas dos livros nas mãos. Apesar de muitos afirmarem compreender a facilidade e praticidade dos "gadgets" de leitura digital, ainda assim, afirmam preferir as sensações que os livros físicos os proporcionam. Isso mostra que a geração $Z$ se importa não apenas com o produto que consome, mas com toda a experiência que ele dá para aquele que o usa.

Podemos concluir também através das entrevistas que há uma grande fidelização por parte dos consumidores com relação a Amazon devido aos planos de assinatura oferecidos pela empresa, o Amazon Prime, que dá o benefício do frete grátis para alguns produtos e promoções exclusivas.

Como a grande preocupação do público entrevistado é principalmente o preço do produto, essas assinaturas agregam muito valor à marca, já que fazem com o valor percebido ${ }^{18}$ pelo cliente seja mais alto já que ele valoriza a economia no momento da compra.

Outra conclusão que podemos chegar através da análise das entrevistas é que um atendimento ao cliente de qualidade também é muito importante para que o consumidor se torne leal a marca ou loja em que estão realizando suas compras. Indo de acordo com as tendências de marcado, a pesquisa mostrou que consumidores de canais digitais já estão mais exigentes quando realizam suas compras e afirmam esperar principalmente rapidez na resolução dos problemas. Caso o suporte dado ao cliente diante de situações adversas que ocorrem durante e pós a compra não esteja dentro do padrão imposto pelo consumidor, ele evita fazer compras na loja no futuro. Entretanto, caso ocorra qualquer problema e o suporte ao cliente seja satisfatório e atenda aos critérios dos consumidores, eles retornarão à loja para realizar mais compras.

${ }^{18}$ A definição de valor percebido pelo cliente, segundo Kotler e Armstrong, no livro Princípios de Marketing (2015), é "a avaliação que o cliente faz da diferença entre todos os benefícios e todos os custos de uma oferta ao mercado em relação às ofertas concorrentes". 
Logo, foi possível notar que, a assinatura de planos que oferecem benefícios nas compras realizadas no e-commerce da empresa e a confiança no serviço oferecido são os principais fatores que levam os membros da geração $Z$ entrevistados a escolherem a Amazon como o canal para a realização das compras.

Com isso, fomos capazes de observar que o perfil dos consumidores é bastante similar em diversos aspectos, apesar de não é muito definido, já que possuem diferentes características e preocupações no momento da compra. Alguns relataram ter se preocupar com a parte ética das empresas onde realizam suas compras, entretanto para outros, esse não é um ponto tão relevante.

Durante as compras na Amazon, as entrevistas nos permitiram observar que os clientes geralmente entram no site com uma compra definida e preferem realizar suas compras através do aplicativo da empresa, nos seus celulares. Além disso, a maior parte do público entrevistado relatou não fazer buscas comparativas em outros marketplaces, e que na maioria das vezes vai direto na Amazon quando deseja realizar uma compra de livro físico online, mostrando como os clientes da empresa são fiéis e confiam nela.

Já com relação à inibição das compras online, a maioria relatou como o principal fator para tal foi o preço final da compra, destacando mais uma vez como o preço é de extrema importância para os compradores da geração Z .

Em geral, foi possível notar ao longo do trabalho as mudanças no comportamento do consumidor da geração $Z$, principalmente com o início da pandemia da Covid-19. Foi possível observar também algumas tendências que provavelmente se manterão mesmo após o fim das medidas restritivas, já que os clientes já se sentem adaptados neste meio de compra.

Tais pontos são de extrema importância, não apenas para lojas e marcas (tanto no momento atual, quanto no futuro próximo), mas também para estudiosos, já que reúnem dados recentes relacionados ao comportamento do consumidor no momento de pandemia.

A pesquisa também foi extremamente relevante e proveitosa para meu crescimento profissional e acadêmico. O comportamento do consumidor digital é um assunto muito atual e o aprofundamento nele é um grande diferencial. 


\subsection{Sugestões e recomendações para novos estudos}

Pelo comércio eletrônico ser um canal de compras relativamente novo, e principalmente, devido ao "boom" que ele sofreu com o avanço da pandemia da Covid-19, ainda existem diversas linhas de estudo que podem ser abordadas.

Estudos comparativos de dados obtidos de nas compras online durante os anos pré-pandemia, de pandemia e pós-pandemia. Estes serão interessantes para que possamos analisar melhor quais mudanças no comportamento dos consumidores ocorreram devido a pandemia e se mantiveram mesmo após o fim dela, quando houver o fim das medidas restritivas e todos nós voltarmos para o "velho normal".

Assim, futuros estudos podem abordar tanto de forma qualitativa, quanto de forma quantitativa, já que o assunto é bastante atual. Recomendo que seja feita uma pesquisa em larga escala e que mostre dados de grande abrangência. 


\section{Referências}

Dossiê Amazon no Brasil - 0 que a gigante tem feito no país. Rock Content, 2019.2 Disponível em: $<$ https://inteligencia.rockcontent.com/amazon-no-brasil/> Acesso em 17 de março de 2021.

E-commerce deve faturar $\mathbf{R} \$ 111$ bi no Brasil em 2020, aponta Kearney. Ecommerce Brasil, 2020. Disponível em: < https://www.ecommercebrasil.com.br/noticias/ecommerce-fatura-bilhoes-brasil2020-kearney/> Acesso em 17 de março de 2021.

Veja os itens que os brasileiros mais compraram no Amazon Prime Day. Istoé, 2020. Disponível em: <https://www.istoedinheiro.com.br/vejaos-itens-que-os-brasileiros-mais-compraram-no-amazon-prime-day/> Acesso em 17 de março de 2021.

4 países onde a Amazon impacta os hábitos de compra. FORBES. São Paulo, 2017. Disponível em: $<$ https://forbes.com.br/forbeslife/2017/07/4-paises-onde-a-amazon-mais-impactaos-habitos-de-compra-dos-consumidores/\#foto3> Acesso em 21 de abril de 2021.

Relatório Varejo de 2021 desvenda o consumidor brasileiro no pós-pandemia. ADYEN. São Paulo, 2021. Disponível em: $<$ https://www.adyen.com/pt_BR/blog/relatorio-varejo-2021-analisacomportamento-consumidor-brasileiro-no-pos-pandemia> Acesso em 26 de maio de 2021.

ADYEN. Relatório Varejo 2021. São Paulo, 2021. Disponível em: $<$ https://www.adyen.com/pt_BR/landing/online/br/2021/relatorio-varejo2021/relatoriocompleto?utm_medium=Content\&utm_source=Blog\&utm_campaign=2021.02CP-BR-Blog\%20Post> Acesso em 26 de maio de 2021.

AGUIAR, Ana Carolina Wuensche Ciuffo; STEINHÄUSER, Vivian. Branded Content - Ferramenta Estratégica de Marketing e seu Impacto no Consumidor. PMKT - Revista Brasileira de Pesquisas de Marketing, Opinião e Mídia (on-line) | ISSN 2317-0123 | São Paulo, Vol. 12, N. 2, 142-159, maioagosto, 2019.

CERETTA, Simone Beatriz; FROEMMING, Lurdes Marlene. Geração Z: Compreendendo os hábitos de consumo da geração emergente. RAUnP ISSN 1984-4204 v.3 n.2 - Abr./Set. 2011, p. 16-24

CLARKE III, Irvine; FLAHERTY, Theresa B. Advances in Eletronic Marketing. Hershey: IGI Publishing. 2005.

COMO as pessoas consomem no e-commerce. ÉPOCA NEGÓCIOS, 2017. Disponível em:

<https://epocanegocios.globo.com/Tecnologia/noticia/2017/09/como-pessoasconsomem-no-e-commerce.html> Acesso em 07 de abril de 2021. 
CONFEDERAÇÃO Nacional de Dirigentes Lojistas (CNDL); SPC Brasil. Comportamento de Compra do Consumidor Online. Brasil, 2017. Disponível em: < $\quad$ https://www.spcbrasil.org.br/wpimprensa/wpcontent/uploads/2017/07/An\%C3\%A1lise-Consumo-Online-_Processos-de-

Compras-e-Impulsividade.pdf > Acesso em 01 de abril de 2021.

CRITEO. Relatório sobre a Geração Z. Estados Unidos, 2018. Disponível em: < http://www.criteo.com/br/wp-content/uploads/sites/5/2018/08/18-GenZ-ReportBR.pdf> Acesso em 07 de abril de 2021.

DINIZ, Eduardo Henrique. Comércio Eletrônico: Fazendo Negócios por meio da Internet. RAC, v. 3, n. 1, Jan./Abr. 1999, p. 71-86.

FAILLA, Zoara; FERREIRA, Claudiney; ROSENDO, Rosi; MILITÃO, Guilherme; MAGALHÃES, Taís; CARVALHO, Alexandre. Retratos da leitura no Brasil - 5a Edição. Brasil, 2021. Disponível em: < https://www.prolivro.org.br/5a-edicao-deretratos-da-leitura-no-brasil-2/a-pesquisa-5a-edicao/> Acesso em 01 de abril de 2021.

FEGHALI, M. K.; DWYER, D. As engrenagens da moda. Rio de Janeiro: Ed. Senac, 2004.

FELIPINI, Dailton; Empreendedorismo na Internet. 3ª Ed. São Paulo. LeBooks, 2012.

GAO, Yuan. Web Systems Design and Online Consumer Behavior. New Jersey: IGI Publishing, 2005

GIL, Antonio Carlos. Como elaborar projetos de pesquisa. 4aㅡ. Ed. São Paulo: Atlas, 2002.

GIGLIO, Ernesto. Comportamento do Consumidor. 3 $3^{\text {a }}$ Ed. São Paulo: Thonsom Pioneira, 2005.

HAGGERTY, Maria. 4 Ways Covid-19 Changed Online Consumer Behavior. Inc., 2020. Disponível em: <https://www.inc.com/maria-haggerty/four-ways-covid19-changed-online-consumer-behavior.html> Acesso em 26 de maio de 2021.

IBGE. POF - Pesquisa de Orçamentos Familiares. Disponível em: <https://biblioteca.ibge.gov.br/visualizacao/livros/liv50063.pdf>. Acesso em $18 \mathrm{de}$ maio de 2021.

KOTLER, Phillip; KELLER, Kevin L. Administração de marketing. 14a Ed. São Paulo: Editora Pearson Education do Brasil, 2012.

LARENTIS, Fabiano. Comportamento do Consumidor / Fabiano Larentis Curitiba, PR: Editora IESDE, 2012.

LEVY, Michael; WEITZ, Barton A. Administração de Varejo. São Paulo: Atlas, 2000.

LOUREIRO, Rodrigo. Amazon tem receita de US\$386 bilhões em 2020 e dobra lucro no 4 trim. EXAME. São Paulo, 2021. Disponível em: $<$ https://exame.com/tecnologia/amazon-tem-receita-de-us-386-bilhoes-em-2020e-dobra-lucro-no-4o-tri/> Acesso em 21 de abril de 2021. 
MATTAR, Fauze Najib. Pesquisa de Marketing. 5를. São Paulo: Atlas, 2012.

MOWEN, John. C.; MINOR, Michael S. Comportamento do Consumidor. $1^{\underline{a}}$ Ed. São Paulo: Prentice Hall, 2003.

NIELSEN; SINDICATO Nacional dos Editores de Livros. Painel do Varejo de Livros no Brasil. Brasil, 2021. Disponível em: < https://snel.org.br/wp/wpcontent/uploads/2021/03/SNEL_02_2021_-_02T_2021.pdf > Acesso em $01 \mathrm{de}$ abril de 2021.

PwC. Total Retail 2017: Alternativas de investimento num mercado cada vez mais competitivo. Brasil, 2017.2 Disponível em: $<$ https://www.pwc.com.br/pt/totalretail/2017/total-retail-2017.pdf> Acesso em 21 de abril de 2021.

SHIFFMAN, Leon G.; KANUK, Leslie L. Comportamento do Consumidor. 6a Ed. Rio de Janeiro: LTC, 2000.

STONE, Brad. A Loja de Tudo: Jeff Bezos e a Era da Amazon. Edição Digital. Rio de Janeiro: Editora Intríseca, 2014.

VEIGA NETO, Alipio Ramos et al. Fatores que influenciam os consumidores da Geração Z na compra de produtos eletrônicos. RACE, Revista de Administração, Contabilidade e Economia, Joaçaba: Ed. Unoesc, v. 14, n. 1, p. 287-312, jan./abr. $2015 . \quad$ Disponível em:

https://dialnet.unirioja.es/descarga/articulo/5160816.pdf> Acesso em 01 de abril de $2021 \mathrm{~A}$ 


\section{Anexo 1}

\section{Perguntas Entrevista Consumo de Livros Físicos na Amazon pela Geração Z}

1. Em um ano, quantos livros em média você compra?

2. Quantos desses são livros de romance?

3. Em que formato você prefere ler? Por quê?

4. Você compra livros físicos através de canais digitais. Por que o faz dessa forma? Quais os benefícios que o fazem escolher esse canal para as suas compras?

5. Quando entra no site da Amazon, sua compra já está definida, ou seja, você já sabe qual título você irá comprar, ou a decisão é feita por impulso?

6. Você faz pesquisas em outros marketplaces antes de comprar na Amazon? O que você busca nessa pesquisa?

7. Com que frequência costuma comprar livros no site Amazon? O que te leva a consumir nesse marketplace, ou seja, qual o diferencial da Amazon com relação a outros canais digitais que o leva a consumir nela?

8. Quantos livros físicos (da categoria de romances) você compra através da Amazon?

9. Por qual canal você prefere realizar suas compras na Amazon? (ex.: Celular, Tablet, Computador...)

10. O que mais levam em consideração no momento da compra? (ex.: frete, preço, tempo de entrega, disponibilidade...)

11. Você já desistiu de alguma compra de livros online? O que o fez desistir, ou seja, o que inibiu a sua compra?

12. E na Amazon? Você já desistiu de alguma compra de livros online? O que o fez desistir, ou seja, o que inibiu a sua compra? 


\section{Anexo 2}

\section{Compilado das Entrevistas}

\section{ENTREVISTADO 1}

Ana Beatriz: Bom, vamos começar então. Eu já estou gravando, ok? ENTREVISTADO 1: Ok, sem problemas.

Ana Beatriz: Primeira pergunta! Em um ano, quantos livros em média você compra?

ENTREVISTADO 1: Cara, nesse último ano com a pandemia eu devo ter comprado cerca de 40 livros. Eu dupliquei a quantidade de livros que eu comprava antes, que girava em torno de 20.

Ana Beatriz: E quantos desses são livros de romance?

ENTREVISTADO 1: Todos. (Risos) Chutaria assim uns $90 \%$, eu leio muito poucos livros que não sejam de romance, biografias, poesias... Mas eu diria uns $90 \%$.

Ana Beatriz: Então, mais ou menos uns 36 livros?

ENTREVISTADO 1: Isso! Mais ou menos...

Ana Beatriz: $\mathrm{E}$ em que formato você prefere ler? Físico ou Digital? ENTREVISTADO 1: Físico!

Ana Beatriz: Por quê?

ENTREVISTADO 1: Gosto da sensação de ter o livro na mão, passar as páginas, gosto do cheirinho também de livro novo. É... eu sei que eu leio muito na rua e que o livro digital seria mais prático, por ser mais leve e tal, mas eu não consigo ter a sensação de que eu estou lendo alguma coisa. E a luz me incomoda também... Não consigo ler muito tempo em celular ou Kindle, o que quer que seja.

Ana Beatriz: Você compra livros físicos através de canais digitais, ou seja, você compra através da internet.

ENTREVISTADO 1: Sim

Ana Beatriz: Por que o faz dessa forma? Quais os benefícios que o fazem escolher esse canal para as suas compras?

ENTREVISTADO 1: Por "n" motivos. Acho que o primeiro deles talvez seja a disponibilidade, então quando eu nãoo acho na loja física, depois agora a pandemia, terceiro em muitos lugares eu tenho o frete grátis 
então o mesmo livro que eu consigo na loja eu consigo também online e às vezes eu também consigo cupom, e sai mais barato comprar online. Eu até gosto da experiência da loja, tá? Mas aqui só estou enumerando os pontos que me levam a comprar online.

Ana Beatriz: Tudo bem! Eu entendo...

ENTREVISTADO 1: E cara, é rápido. Eu estou agora no clube do livro, então às vezes preciso de um livro e não tenho tempo de ir na livraria. Eu preciso que esse livro chegue rápido porque eu tenho um mês para ler. Ele chega aqui na minha casa em dois dias, sem frete, porque eu tenho Amazon Prime, e muitas vezes mais barato. Isso é mais rápido do que eu pegar meu carro e ir na livraria comprar.

Ana Beatriz: Quando entra no site da Amazon, sua compra já está definida, ou seja, você já sabe qual título você irá comprar, ou a decisão é feita por impulso?

ENTREVISTADO 1: Então, muitas vezes ela já vai definida falando em termos gerais, mas quando é livro, se for na Amazon, eu tenho Amazon Prime né? Então muitas vezes o frete é grátis. Mas eu tenho uma lista de livros interminável e se eu tiver que pagar pelo frete, eu penso assim "Já estou pagando frete", então eu acrescento mais livros na minha compra para fazer valer o frete que eu vou pagar.

Ana Beatriz: Você faz pesquisas em outros lugares antes de comprar na Amazon? O que você busca nessa pesquisa?

ENTREVISTADO 1: Quando eu tenho que comprar livro online eu geralmente procuro em sites de livrarias menores. Mas nesses lugares geralmente o prazo de entrega é muito longo e como eu disse aquilo do clube do livro, muitas vezes o prazo de entrega é o tempo que eu tenho para ler o livro. Ou não tem o livro em estoque e eles vão comprar pra entregar, ai o prazo de entrega fica de 30 dias... Nesses casos eu geralmente vou para a Amazon. Ou se, por exemplo, tem uma diferença grande de preço de mais de 15 ou 20 reais. Então assim, em ordem de prioridade pra mim é disponibilidade em primeiro lugar, depois prazo de entrega e por último preço.

Ana Beatriz: Com que frequência costuma comprar livros no site Amazon?

ENTREVISTADO 1: Todo mês. Eu tenho uma lista interminável de livros que eu quero ler e mensalmente eu vou na Amazon e faço uma compra 
grande de livros dessa lista e também de outros produtos que eu compro pra casa por exemplo.

Ana Beatriz: $O$ que te leva a consumir nesse marketplace, ou seja, qual o diferencial da Amazon com relação a outros canais digitais que o leva a consumir nela?

ENTREVISTADO 1: Pra mim em particular tem a vantagem do Amazon Prime, que geralmente é a entrega rápida e sem frete. Além disso eu gosto do fato de ser a própria Amazon que vende, e não outros vendedores. Eu sei que tem outros vendedores na Amazon, mas eu compro sempre direito da Amazon porque eu acho mais confiável... Fico com medo de comprar e o produto vir danificado, ou eu não receber o produto que eu comprei. Aquelas histórias que a gente ouve quase que de terror, né? (Risos) Então basicamente, porque com a Amazon eu sei que eu não vou ter dor de cabeça. E o preço que ela pratica. Ela consegue fazer descontos muito bons nos livros que ela vende, o que é muito bom... Apesar de em livros o preço não ser uma prioridade tão grande para mim.

Ana Beatriz: Quantos livros físicos (da categoria de romances) você compra através da Amazon?

ENTREVISTADO 1: Ah... mais ou menos uns $20 \%$, então eu diria que uns 8 livros.

Ana Beatriz: Por qual canal você prefere realizar suas compras na Amazon? (ex.: Celular, Tablet, Computador...)

ENTREVISTADO 1: App! No meu celular né? É ótimo, não preciso nem colocar o código de segurança quando eu compro.

Ana Beatriz: 0 que mais levam em consideração no momento da compra? (ex.: frete, preço, tempo de entrega, disponibilidade...)

ENTREVISTADO 1: Prazo de entrega, com certeza.

Ana Beatriz: Você já desistiu de alguma compra de livros online? 0 que o fez desistir, ou seja, o que inibiu a sua compra?

ENTREVISTADO 1: Sim! Desses meus impulsos em promoções. Coloco tudo no carrinho e depois percebo que ainda tenho muito livros já comprados para ler, aqui do lado da minha cama. Ai penso melhor e vejo que não faz sentido comprar todos os livros naquele momento. Eu vou falar a verdade, quando o preço final fica muito alto, sabe? Eu me assusto e vou rever o que tem no meu carrinho. Nisso acabo fazendo meio que uma triagem do que eu coloquei no carrinho para ver o que eu 
realmente quero e preciso... e também que vale a pena naquele momento.

Ana Beatriz: E na Amazon? Você já desistiu de alguma compra de livros online? $O$ que 0 fez desistir, ou seja, o que inibiu a sua compra?

ENTREVISTADO 1: Ah... é a mesma coisa.

\section{ENTREVISTADO 2}

Ana Beatriz: Bom, já está gravando ok?

ENTREVISTADO 2: Tudo bem!

Ana Beatriz: Vou começar...A primeira pergunta é: em um ano, quantos livros em média você compra?

ENTREVISTADO 2: Uns... 25, 30. Por ai.

Ana Beatriz: Beleza! E quantos desses são de romance?

ENTREVISTADO 2: Provavelmente uns 40, 50\%.

Ana Beatriz: Em que formato você prefere ler? Físico ou Digital?

ENTREVISTADO 2: Hoje em dia digital, mas só recentemente comecei a comprar mais digital.

Ana Beatriz: E por que você prefere o digital?

ENTREVISTADO 2: Pela Praticidade, pelo custo... Assim eu fico muito fora de casa, para ir trabalhar, indo para ensaio, então fica muito mais fácil para mim. E também fica bem mais barato né? Eu tenho Kindle Unlimited também, então fica bem mais barato.

Ana Beatriz: Bom, sabemos que você compra livros físicos através de canais digitais.

ENTREVISTADO 2: Compro sim.

Ana Beatriz: E por que o faz dessa forma? Qual benefício que te faz escolher a Amazon para comprar?

ENTREVISTADO 2: Ah... agora com pandemia e tal a gente quase não tem oportunidade de sair. Então a internet está ali, no alcance o tempo todo... A gente entra na Amazon para dar uma olhada, quando você vai ver você já comprou alguns livros. Então, é a praticidade mesmo, a facilidade.

Ana Beatriz: E quando entra no site da Amazon, sua compra já está definida, então assim... você já sabe qual título você vai comprar, ou a decisão é feita por impulso? 
ENTREVISTADO 2: Normalmente, eu já tenho uma compra definida, mas muitas vezes pelas promoções que eles fazem, eu vou pelo impulso. Acontece menos, mas não posso dizer que não acontece.

Ana Beatriz: E você pesquisa em outros marketplaces antes de comprar na Amazon?

ENTREVISTADO 2: É raro, só quando eu acho que o preço está acima daquilo que eu espero... Mas geralmente eu entro na Amazon e compro direto.

Ana Beatriz: Bom, e o que você busca nessa pesquisa?

ENTREVISTADO 2: Ah... eu vejo o preço, histórico de promoções, vejo com amigos se o preço está valendo, entendeu? Mas assim, basicamente o preço.

Ana Beatriz: Com que frequência costuma comprar livros no site Amazon?

ENTREVISTADO 2: Pelo menos umas duas ou três vezes por mês.

Ana Beatriz: $O$ que te leva a consumir nesse marketplace, ou seja, qual o diferencial da Amazon com relação a outros canais digitais que te leva a consumir nela?

ENTREVISTADO 2: Para mim é principalmente a questão do frete, porque eu tenho Amazon Prime, então eu não pago frete na grande maioria das minhas compras. E o preço, porque normalmente eles colocam muitas promoções, então acaba valendo mais a pena... Então é isso. Mas principalmente o frete. Essa questão do frete para mim é o maior diferencial.

Ana Beatriz: Quantos livros físicos de romance você compra através da Amazon?

ENTREVISTADO 2: Pelo menos um por mês.

Ana Beatriz: E por qual canal você prefere realizar suas compras na Amazon? Celular, Tablet, Computador...

ENTREVISTADO 2: Celular.

Ana Beatriz: No momento da compra, o que você mais leva em consideração?

ENTREVISTADO 2: Para mim a prioridade do momento que eu vou ler o livro, então se é um livro que eu quero muito ler por agora... E preço.

Ana Beatriz: Você já desistiu de alguma compra de livros online?

ENTREVISTADO 2: Hum... Já desisti de compras por impulso. Nessas promoções eu acabo colocando muita coisa no carrinho na animação... 
Depois quando eu vou olhar eu penso melhor e acabo cancelando o pedido.

Ana Beatriz: 0 que o fez desistir? 0 que inibiu a sua compra?

ENTREVISTADO 2: Pela questão do impulso. Tipo, eu realmente preciso desse livro agora, ou eu posso comprar em outro momento. Por que eu estou comprando? Por que está barato ou porque eu quero realmente ler?

Ana Beatriz: Agora a mesma pergunta para a Amazon... Você já desistiu de alguma compra de livros lá? 0 que o fez desistir? ENTREVISTADO 2: Mesma coisa... Nunca tive nenhum outro tipo de problema com eles, então é a mesma coisa de todos os lugares.

Ana Beatriz: É isso acabou! Vou desligar aqui o gravado, ok?

ENTREVISTADO 2: Ah! Que rápido! Ok, pode desligar sim!

\section{ENTREVISTADO 3}

Ana Beatriz: A primeira pergunta é: Em um ano, quantos livros em média você compra?

ENTREVISTADO 3: Ah acho que uns 70.

Ana Beatriz: Quantos desses são livros de romance?

ENTREVISTADO 3: Acho que mais ou menos 30.

Ana Beatriz: Em que formato você prefere ler? Físico ou Digital?

ENTREVISTADO 3: Físico!

Ana Beatriz: E por quê?

ENTREVISTADO 3: Eu gosto de sentir o livro, de mexer no papel e de ter na minha estante principalmente.

Ana Beatriz: Você compra livros físicos através de canais digitais.

ENTREVISTADO 3: Sim, sim.

Ana Beatriz: Por que o faz dessa forma? Quais os benefícios que te fazem escolher esse canal para as suas compras?

ENTREVISTADO 3: Primeiramente, não ter que sair da minha casa. $O$ segundo é o preço. É muito diferente o preço do livro nas livrarias e na internet. $\mathrm{E}$ é isso.

Ana Beatriz: Quando entra no site da Amazon, sua compra já está definida, ou seja, você já sabe qual título você irá comprar, ou a decisão é feita por impulso?

ENTREVISTADO 3: Por impulso, sempre. 
Ana Beatriz: Você faz pesquisas em outros marketplaces antes de comprar na Amazon? O que você busca nessa pesquisa?

ENTREVISTADO 3: Hoje em dia não mais, mas antes da pandemia eu procurava em livrarias e na Amazon, e só. Hoje em dia eu compro só na Amazon mesmo.

Ana Beatriz: Com que frequência costuma comprar livros no site Amazon?

ENTREVISTADO 3: Todo mês.

Ana Beatriz: $O$ que te leva a consumir nesse marketplace, ou seja, qual o diferencial da Amazon com relação a outros canais digitais que o leva a consumir nela?

ENTREVISTADO 3: Eu já estou acostumada a usar a plataforma e eu me sinto confortável usando-a. O preço é muito bom, tem muitas promoções... O que mais? Ah... o atendimento ao cliente deles é muito bom. Sempre que eu tive algum problema eu fui atendida muito rápido e foi tudo muito bem resolvido... Então acho que esses são os principais diferenciais.

Ana Beatriz: Quantos livros físicos (da categoria de romances) você compra através da Amazon?

ENTREVISTADO 3: No ano, por volta de 30 mesmo.

Ana Beatriz: Por qual canal você prefere realizar suas compras na Amazon? (ex.: Celular, Tablet, Computador...)

ENTREVISTADO 3: Celular, no aplicativo.

Ana Beatriz: O que mais levam em consideração no momento da compra? (ex.: frete, preço, tempo de entrega, disponibilidade...)

ENTREVISTADO 3: Preço.

Ana Beatriz: Você já desistiu de alguma compra de livros online?

ENTREVISTADO 3: Desistir? Ah sim... eu geralmente coloco tudo no meu carrinho e depois faço uma limpa.

Ana Beatriz: E o que te fez desistir, ou seja, o que inibiu a sua compra?

ENTREVISTADO 3: Eu boto a mão na consciência e vejo que eu não preciso de mais livro... Tenho muitos aqui em casa ainda para ler.

Ana Beatriz: E na Amazon?

ENTREVISTADO 3: Ah, mesma coisa né? Eu praticamente só compro na Amazon... Muito difícil comprar em outro lugar. 


\section{ENTREVISTADO 4}

Ana Beatriz: Bom, estou gravando ok? E eu queria começar te agradecendo muito por você topar ser entrevistada!

ENTREVISTADO 4: Ah, que isso! Problema nenhum... No que eu puder ajudar....

Ana Beatriz: Bom, vamos começar... Em um ano, quantos livros em média você compra?

ENTREVISTADO 4: Comparando os outros anos e o ano da pandemia, teve uma variante assim muito grande, mas eu vou colocar ai em média uns 20 livros.

Ana Beatriz: E quantos desses de romance?

ENTREVISTADO 4: Ah! (Risos) Eu acho que 10 livros.

Ana Beatriz: E você prefere ler em que formato? Físico ou Digital?

ENTREVISTADO 4: Eu prefiro ler no digital, mas se eu gostar eu compro no físico.

Ana Beatriz: E por quê?

ENTREVISTADO 4: É mais cômodo e não cansa muito a minha vista.

Ana Beatriz: Bom, a gente sabe que você compra livros físicos através de canais digitais.

ENTREVISTADO 4: Isso.

Ana Beatriz: Por que você faz dessa forma? Quais são os benefícios que fazem com que você escolha esse canal para as suas compras? ENTREVISTADO 4: Preço. Com certeza preço. E também é mais cômodo não ter que sair de casa para comprar meu livro, né?

Ana Beatriz: Quando entra no site da Amazon, a sua compra já está definida, ou você vai mais pelo impulso?

ENTREVISTADO 4: É... Geralmente minha compra já está definida, porque eu fico acompanhando os preços, sabe? Mas se tem a promoção de algum livro que eu quero e eu não estava esperando, então eu acho que eu compro, mas normalmente eu planejo minhas compras.

Ana Beatriz: Você faz pesquisas em outros marketplaces antes de comprar na Amazon?

ENTREVISTADO 4: Não, geralmente eu compro direto na Amazon e não procuro em outros lugares.

Ana Beatriz: Com que frequência costuma comprar livros no site Amazon? 
ENTREVISTADO 4: Sempre que eu compro é lá... Algumas vezes compro na física, em casos em que há promoções como livros por 10 reais, mas normalmente compro na Amazon mesmo.

Ana Beatriz: $O$ que te leva a consumir nesse marketplace. Assim, qual o diferencial da Amazon com relação a outros canais digitais que te leva a consumir nela?

ENTREVISTADO 4: Para mim é o frete grátis. Porque assim, eu assino o Amazon Prime, então para mim acaba valendo mais a pena. E o preço também.

Ana Beatriz: Quantos livros físicos da categoria de romances você compra através da Amazon?

ENTREVISTADO 4: Praticamente todos. Comprei só um no último ano na loja física.

Ana Beatriz: Por qual canal você prefere realizar suas compras na Amazon? Celular, Tablet, Computador...

ENTREVISTADO 4: Celular mesmo.

Ana Beatriz: 0 que mais levam em consideração no momento da compra? É o frete, preço, tempo de entrega, disponibilidade...

ENTREVISTADO 4: O preço mesmo... Porque como eu tenho Amazon Prime, o frete não vira nem uma questão.

Ana Beatriz: Você já desistiu de alguma compra de livros online?

ENTREVISTADO 4: Sempre coloco no carrinho e depois penso melhor... Nossa, muitas e muitas vezes.

Ana Beatriz: E o que o fez desistir, ou seja, o que inibiu a sua compra?

ENTREVISTADO 4: Preço. (Risos) Isso sempre empaca um pouco para mim.

Ana Beatriz: Agora a mesma pergunta para a Amazon? Você já desistiu de alguma compra de livros lá? E o que te fez desistir?

ENTREVISTADO 4: Na Amazon a mesma coisa, sempre desisto por causa do preço.

Ana Beatriz: Acabou! É isso.... Vou parar de gravar aqui, beleza?

ENTREVISTADO 4: Ah! Beleza!

\section{ENTREVISTADO 5}

Ana Beatriz: Pronto ${ }^{\star \star \star *}$, comecei a gravar, ok?

ENTREVISTADO 5: Beleza! 
Ana Beatriz: E vou te agradecer mais uma vez por você topar participar aqui da entrevista!

ENTREVISTADO 5: Nada, que isso! Que bom que eu vou conseguir ajudar!

Ana Beatriz: Bom Babi, primeira pergunta... Em um ano, quantos livros em média você compra?

ENTREVISTADO 5: Cara, ano passado eu li bastante... eu diria que mais ou menos uns 10 livros por ano.

Ana Beatriz: E quantos desses são de romance?

ENTREVISTADO 5: Eu gosto muito de romance e crônica assim, sabe?

Então a maioria é de romance.... diria que uns 7 livros.

Ana Beatriz: E em que formato você prefere ler? Físico ou Digital?

ENTREVISTADO 5: Hoje em dia eu prefiro o digital, apesar de eu gostar muito de livro físico também.

Ana Beatriz: E por quê?

ENTREVISTADO 5: Pela praticidade do digital, sabe? Se você está no aeroporto você liga, se você está no sol ele se adapta... Eu leio muito no sol, então o que mais me encantou no digital foi eu conseguir ler sem cansar tanto a minha vista.

Ana Beatriz: Bom, a gente sabe que você compra livros físicos através de canais digitais.

ENTREVISTADO 5: Sim.

Ana Beatriz: E por que utiliza esse canal para as suas compras? Quais são os benefícios que esse canal te dá para que você escolha ele para fazer as suas compras?

ENTREVISTADO 5: Então, eu tenho, ou melhor, tinha muito o hábito de entrar em uma livraria física, ver um livro que eu gostei e comprar... Mas o que eu gosto muito na Amazon é a praticidade também, porque você lê a sinopse do livro, você vê a capa, como ele é, você compra e ele chega muito rápido na sua casa... Então, assim, nessa época de pandemia que a gente está passando, principalmente pra mim, ficou muito mais fácil para eu conseguir comprar meus livros do que ir em algum lugar, me expor... E você espera no máximo 3 dias pelo livro, sabe? Então é muito rápido...

Ana Beatriz: E quando entra no site da Amazon, sua compra já está definida, você vai mais pelo impulso? 
ENTREVISTADO 5: Muito pelo impulso... Fora situações em que uma amiga me recomendou alguma coisa e eu vou direto naquilo que ela me falou. Mas a Amazon já tem meu perfil de leitora lá, então quando eu entro, vou direto na parte de recomendados e fico vendo, sabe? Se alguma coisa me interessa, eu compro...

Ana Beatriz: Você faz pesquisas em outros marketplaces antes de comprar na Amazon?

ENTREVISTADO 5: Sim, sim... eu costumo comparar preço, sim.

Ana Beatriz: A próxima pergunta era "E o que você busca nessa pesquisa?" mas você meio que já respondeu... Tem mais alguma coisa que você busca?

ENTREVISTADO 5: Não, assim de lojas e marketplaces eu comparo os preços. Fora isso eu pesquiso um pouco sobre o livro no youtube e instagram, mas não muito porque eu também não quero ganhar um spoiler. (Risos)

Ana Beatriz: E com que frequência costuma comprar livros no site Amazon?

ENTREVISTADO 5: Cara, eu acho que umas cinco vezes por ano.

Ana Beatriz: $E$ o que te leva a consumir nesse marketplace? Assim, qual o diferencial da Amazon com relação a outros canais digitais que o leva a consumir nela?

ENTREVISTADO 5: Além do preço, é isso de ser muito rápido, sabe? E eles são de confiança também... Todas as vezes que eu tive um problema eu fui atendida muito rápido pelo suporte deles.

Ana Beatriz: Quantos livros físicos de romance você compra através da Amazon? ENTREVISTADO 5: Físicos?

Ana Beatriz: Sim!

ENTREVISTADO 5: Acho que hoje em dia uns 2 ou 3 livros físicos de romance por ano... o resto é mais digital.

Ana Beatriz: E por qual canal você prefere realizar suas compras na Amazon? Celular, Tablet, Computador...

ENTREVISTADO 5: Computador e celular... Mas eu diria que hoje em dia eu compro mais pelo celular, acho muito prático.

Ana Beatriz: 0 que mais levam em consideração no momento da compra?

ENTREVISTADO 5: Cara, acho que muito a capa do livro... Essa é uma coisa que eu observo. Quando eu compro livro físico, geralmente é 
porque eu amo a autora, como é o caso da Collen Hover ou eu acho que o livro tem uma capa bonita que vai servir de decoração pra mim também sabe? Então a capa é uma coisa que sempre pesa quando eu compro... Ana Beatriz: E você já desistiu de alguma compra de livros online? ENTREVISTADO 5: Ah já!

Ana Beatriz: 0 que o fez desistir, ou seja, o que inibiu a sua compra?

ENTREVISTADO 5: Algumas vezes, sei lá... Eu estou com muitos livros parados para ler ainda, então não vou comprar mais um. E outras vezes é tipo... Está caro, vou esperar uma promoção para eu comprar.

Ana Beatriz: E na Amazon? Você já desistiu de alguma compra de livros online lá?

ENTREVISTADO 5: A plataforma digital que eu mais compro livro é a Amazon, né? Então assim, quando desisti de comprar foi lá.

Ana Beatriz: $E$ as razões que te fizeram desistir lá, foram...

ENTREVISTADO 5: A mesma coisa, a questão de já ter muito livro digamos que "encalhado" em casa e também o preço.

\section{ENTREVISTADO 6}

Ana Beatriz: Bom, amiga, a gente está gravando agora. Vou te fazer a primeira pergunta... Em um ano, quantos livros em média você compra?

ENTREVISTADO 6 Dias: Pela Amazon, ou no total?

Ana Beatriz: No total... Físico ou digital, comprado onde for...

ENTREVISTADO 6: Ah, beleza... Acho que uns 7 no total.

Ana Beatriz: E quantos desses são livros de romance?

ENTREVISTADO 6: Eu comprei dois físicos de romance. O resto é de arquitetura.

Ana Beatriz: Em que formato você prefere ler? Físico, digital....

ENTREVISTADO 6: Prefiro físico!

Ana Beatriz: E por quê?

ENTREVISTADO 6: Porque... Não sei, eu sinto mais prazer lendo físico.

E eu não tenho Kindle, então quando eu leio online, eu leio pelo Ipad e a luz me incomoda bastante, meus olhos ficam doendo.

Ana Beatriz: Bom, sabemos que você compra livros físicos através de canais digitais. Por que você faz dessa forma? Quais os benefícios que te fazem escolher esse canal para as suas compras? 
ENTREVISTADO 6: Única e exclusivamente o preço. Quando eu vou nas livrarias físicas eu vejo lá o livro, dou uma folheada e se eu achei interessante, eu deixo lá e vejo, seja na Amazon ou em qualquer outro site por quanto eles estão vendendo... Normalmente é mais barato. Até porque tem a opção de comprar o livro usado também né? Então, sempre sai mais barato...

Ana Beatriz: Bom, quando você entra no site da Amazon, sua compra já está definida ou a decisão é feita por impulso?

ENTREVISTADO 6: Não, eu sempre tenho a compra definida.

Ana Beatriz: E você faz pesquisas em outros marketplaces antes de comprar na Amazon?

ENTREVISTADO 6: Sim.

Ana Beatriz: E o que você busca nessa pesquisa?

ENTREVISTADO 6: Preço, né? Que nem eu falei antes...

Ana Beatriz: Com que frequência costuma comprar livros no site Amazon?

ENTREVISTADO 6: Assim, juntando digital e físico, eu compro geralmente a cada 45 dias, eu acho? É... mais ou menos por aí.

Ana Beatriz: $O$ que te leva a consumir nesse marketplace? Assim, qual o diferencial da Amazon com relação a outros canais digitais que o leva a consumir nela?

ENTREVISTADO 6: Calma, deixa eu pensar... Acho que a interface da Amazon é melhor. Ela é sempre o primeiro lugar que eu entro por causa disso. Depois eu vou nos outros comparar.

Ana Beatriz: Quantos livros físicos de romance você comprou através da Amazon? Pensa no último ano, assim...

ENTREVISTADO 6: Os dois que eu comprei esse ano, eu comprei lá.

Ana Beatriz: E por qual canal você prefere realizar suas compras na Amazon? Celular, Tablet, Computador...

ENTREVISTADO 6: Huum... Computador.

Ana Beatriz: E o que você mais leva em consideração no momento da compra?

ENTREVISTADO 6: Preço. (Risos)

Ana Beatriz: E você já desistiu de alguma compra de livros online?

ENTREVISTADO 6: Não, por que sempre que eu penso em comprar um livro eu tenho muita certeza do que eu quero, sabe? Pesquiso muito... 
Então eu nunca coloquei nada no carrinho e desisti. Pelo menos não que eu me lembre...

Ana Beatriz: Na Amazon então você também nunca desistiu... ENTREVISTADO 6: Não que eu me lembre...

Ana Beatriz: Ah então é isso...

\section{ENTREVISTADO 7}

Ana Beatriz: Bom, amiga, a gente está gravando agora, beleza?

ENTREVISTADO 7: Sim senhora! (Risos)

Ana Beatriz: (Risos) Então vamos lá! Em um ano, quantos livros em média você compra?

ENTREVISTADO 7: Acho que uns 30.

Ana Beatriz: E quantos desses são livros de romance?

ENTREVISTADO 7: 25 (Risos)

Ana Beatriz: Em que formato você prefere ler? Físico, digital....

ENTREVISTADO 7: Depende do livro. Tem livro que eu prefiro ler em formato digital e livros que eu prefiro ler físico.

Ana Beatriz: Como é isso? Quais você prefere físicos e quais você prefere digital e por quê?

ENTREVISTADO 7: Geralmente, compro físico aqueles que eu sei que eu vou gostar muito ou de autores que eu gosto muito, tipo a Collen Hoover, sabe? Amo os livros dela e sempre compro físico para poder guardar, uma coisa meio que de colecionador. Mas se for um livro que eu vou ler só de entretenimento mesmo, para passar o tempo, aí eu leio no Kindle mesmo. E os que estão no Kindle Unlimited, eu leio no Kindle por que aí no caso eu não pago né? (Risos)

Ana Beatriz: Bom, sabemos que você compra livros físicos através de canais digitais. Por que você faz dessa forma? Quais os benefícios que te fazem escolher esse canal para as suas compras? ENTREVISTADO 7: No último ano foi a pandemia, sem dúvidas, porque no caso eu não estou saindo de casa para ir à livraria. Então geralmente eu compro na Amazon e na Submarino, e nesses lugares geralmente tem promoções, e o preço acaba sendo mais barato e como eu leio muito, em quantidade, para mim no final do dia faz diferença.

Ana Beatriz: Bom, quando você entra no site da Amazon, sua compra já está definida ou a decisão é feita por impulso? 
ENTREVISTADO 7: Depende, de novo. Meus autores favoritos, eu os sigo nas redes sociais, então quando eu sei que vai lançar o livro deles eu já entro sabendo que eu quero esse livro e vou direto. Mas se eu não tenho nada para ler, eu entro então na Amazon e fico procurando nas categorias.

Ana Beatriz: E você faz pesquisas em outros marketplaces antes de comprar na Amazon e o que você busca nessa pesquisa?

ENTREVISTADO 7: Cara, como eu tenho o Amazon Prime, acaba que eu não pago frete. Então acaba valendo a pena comprar sempre na Amazon, mas às vezes, um livro que eu sei que é lançamento, ou que está acima de 50 reais, então tem um valor mais caro, eu olho para ver se em algum outro lugar está mais barato. Mas se for abaixo de 50 reais, eu nem olho, eu só compro mesmo porque eu sei que eu não vou pagar frete.

Ana Beatriz: Com que frequência costuma comprar livros no site Amazon?

ENTREVISTADO 7: Uma vez a cada dois meses mais ou menos.

Ana Beatriz: $O$ que te leva a consumir nesse marketplace? Assim, qual o diferencial da Amazon com relação a outros canais digitais que o leva a consumir nela?

ENTREVISTADO 7: O prime, então o fato de não pagar o frete. A entrega relâmpago, porque a entrega deles é muito rápida. Eu comprei um presente de Dia das Mães no domingo, chegou na minha casa na segunda. É muito rápido! E eu acho mais fácil de navegar no site. Para mim a usabilidade do site e aplicativo da Amazon é muito melhor do que a dos concorrentes, tipo Submarino... Acho que é o principal concorrente, mas de outros players, tipo Saraiva e tal.

Ana Beatriz: Quantos livros físicos de romance você comprou através da Amazon? Pensa no último ano, assim...

ENTREVISTADO 7: Peraí, deixa eu pensar.... Numa média, acho que dos 25 uns 22.

Ana Beatriz: E por qual canal você prefere realizar suas compras na Amazon? Celular, Tablet, Computador...

ENTREVISTADO 7: Se eu sei o que eu quero, eu vou pelo app, mas se for para ficar navegando eu entro pelo computador.

Ana Beatriz: E o que você mais leva em consideração no momento da compra? 
ENTREVISTADO 7: A história do livro e preço.

Ana Beatriz: E você já desistiu de alguma compra de livros online?

ENTREVISTADO 7: Já!

Ana Beatriz: $O$ que te fez desistir?

ENTREVISTADO 7: Ah, foram situações tipo eu coloquei um livro no carrinho, mas não finalizei a compra. Ai no dia seguinte meu pai me perguntou se eu queria algum livro, então eu desisti daquela compra e ele comprou o livro para mim, sabe?

Ana Beatriz: E na Amazon? Você já desistiu de alguma compra de livros online?

ENTREVISTADO 7: Sim, sim!

Ana Beatriz: $E$ o que te fez desistir?

ENTREVISTADO 7: Preço. Já adicionei o livro no carrinho e fui checar em outros lugares e achei mais barato. Aí eu desisti.

\section{ENTREVISTADO 8}

Ana Beatriz: Bom, a gente está gravando agora, tudo bem?

ENTREVISTADO 8: Beleza! Meu áudio está bom para você?

Ana Beatriz: Está sim! Está perfeito! Posso começar?

ENTREVISTADO 8: Pode sim!

Ana Beatriz: Em um ano, quantos livros em média você compra?

ENTREVISTADO 8: Aí difícil! Acho que no ano passado, eu devo ter comprado uns 50 ou 60 livros.

Ana Beatriz: E quantos desses são livros de romance?

ENTREVISTADO 8: Aí bastante, eu leio bastante romance. Acho que entre $80 \%$ e $90 \%$ desse valor que eu te falei.

Ana Beatriz: Em que formato você prefere ler? Físico, digital....

ENTREVISTADO 8: Físico.

Ana Beatriz: E por quê?

ENTREVISTADO 8: Eu acho mais confortável para a leitura... E não só para a leitura, eu acho mais fácil me concentrar quando eu leio livro físico. No digital, se não estiver tão interessante, eu não consigo fazer a leitura fluir.

Ana Beatriz: Bom, sabemos que você compra livros físicos através de canais digitais. Por que você faz dessa forma? Quais os benefícios que te fazem escolher esse canal para as suas compras? 
ENTREVISTADO 8: Hoje em dia é preço o principal, com certeza. Porque você consegue pesquisar melhor, ver os preços. Tem lojas que dentro da própria loja, entre a loja física e vendo online, né? É mais barato através da compra online... E também o conforto de ter a sua compra chegando na sua casa.

Ana Beatriz: Bom, quando você entra no site da Amazon, sua compra já está definida ou a decisão é feita por impulso?

ENTREVISTADO 8: Então, depende muito. Quando eu vou por impulso, eu vou pelo preço. Na minha última compra, eu comprei um livro que eu nunca tinha pensado em ler, mas ele estava muito baratinho. Li a sinopse e acabei comprando. Mas dificilmente isso acontece, dificilmente eu compro por impulso. Eu tenho o hábito de colocar no carrinho e ficar pensando por um tempo e só compro quando tenho muita certeza.

Ana Beatriz: E você faz pesquisas em outros marketplaces antes de comprar na Amazon?

ENTREVISTADO 8: Então, eu costumava fazer mais. Comparava preço, frete... Essas coisas. Mas agora eu tenho Amazon Prime, então normalmente eu vou direto na Amazon mesmo. Se o preço estiver muito alto, ai eu dou uma comparada com outros sites, mas muito raro.

Ana Beatriz: Você já falou um pouco, mas você busca o que nessa pesquisa?

ENTREVISTADO 8: Preço e, bom, frete. O preço total digamos.

Ana Beatriz: Com que frequência costuma comprar livros no site Amazon?

ENTREVISTADO 8: Acho que uma média de mais ou menos um pedido por mês.

Ana Beatriz: 0 que te leva a consumir nesse marketplace? Assim, qual o diferencial da Amazon com relação a outros canais digitais que o leva a consumir nela?

ENTREVISTADO 8: Para mim é o conforto. O Prime que vai trazer na minha casa, eu sei que eu não vou ter problema... É rápido, meu cartão já está salvo... Mas principalmente o Prime, essa parte toda da entrega... Isso para mim tem sido determinante.

Ana Beatriz: E quantos livros físicos de romance você comprou através da Amazon? Assim no último ano...

ENTREVISTADO 8: No último ano? Nossa... Acho que uns 20. 
Ana Beatriz: E por qual canal você prefere realizar suas compras na Amazon? Celular, Tablet, Computador...

ENTREVISTADO 8: Ah, eu prefiro o computador.

Ana Beatriz: E o que você mais leva em consideração no momento da compra?

ENTREVISTADO 8: Difícil... Eu acho que se vai chegar do jeito que eu quero em casa. Eu não gosto de ter problema. Ai chegou rasgado, ou atrasou, ou qualquer coisa... Então a qualidade da entrega, de como o produto vai chegar na minha casa.

Ana Beatriz: E você já desistiu de alguma compra de livros online?

ENTREVISTADO 8: Ah muito, colocar no carrinho é o meu hobby.

Ana Beatriz: $O$ que te fez desistir?

ENTREVISTADO 8: Se eu não tiver tempo para ele e eu achar que ele vai abaixar. Se o preço não está maravilhoso e eu não quero muito ler ele naquele momento, então eu não compro.

Ana Beatriz: E na Amazon? Você já desistiu de alguma compra de livros online? E se sim, o que te fez desistir?

ENTREVISTADO 8: Na Amazon? Acho que aquela coisa, coloquei no carrinho, continuei navegando e vi um outro que me atraiu mais, que eu queria muito também e estava mais barato. Ai eu pensei assim, ah vou deixar esse mais caro para depois.

\section{ENTREVISTADO 9}

Ana Beatriz: Bom ${ }^{\star \star \star \star *}$, comecei aqui a gravação, beleza?

ENTREVISTADO 9: Beleza!

Ana Beatriz: Vou começar as perguntas... Em um ano, quantos livros em média você compra?

ENTREVISTADO 9: Uns 8, mais ou menos.

Ana Beatriz: E quantos desses são livros de romance?

ENTREVISTADO 9: Uns 8 (Risos)

Ana Beatriz: Em que formato você prefere ler? Físico, digital....

ENTREVISTADO 9: Físico.

Ana Beatriz: E por quê?

ENTREVISTADO 9: Acho que é outra experiência... Você pegar o livro na mão, sentir ele ... 
Ana Beatriz: Bom, sabemos que você compra livros físicos através de canais digitais. Por que você faz dessa forma? Quais os benefícios que te fazem escolher esse canal para as suas compras? ENTREVISTADO 9: Eu acho que a vantagem de você poder fazer isso da sua casa, não precisar pegar o carro, ir para o shopping, em uma livraria... Eu acho mais cômodo e mais rápido.

Ana Beatriz: Bom, quando você entra no site da Amazon, sua compra já está definida ou a decisão é feita por impulso?

ENTREVISTADO 9: Normalmente a minha compra já está definida.

Ana Beatriz: E você faz pesquisas em outros marketplaces antes de comprar na Amazon?

ENTREVISTADO 9: Não, eu vou direto na Amazon mesmo.

Ana Beatriz: Com que frequência costuma comprar livros no site Amazon?

ENTREVISTADO 9: A cada um, dois meses... Digamos um mês e meio, vamos fazer uma média. (Risos)

Ana Beatriz: 0 que te leva a consumir nesse marketplace? Assim, qual o diferencial da Amazon com relação a outros canais digitais que o leva a consumir nela?

ENTREVISTADO 9: A Amazon tem todos os livros, tudo o que eu procuro eu sempre acho lá. Tem tudo de tudo mesmo.

Ana Beatriz: Quantos livros físicos de romance você comprou através da Amazon? Pensa no último ano, assim...

ENTREVISTADO 9: Se não me engano foram dois livros. Os dois últimos que eu comprei.

Ana Beatriz: E por qual canal você prefere realizar suas compras na Amazon? Celular, Tablet, Computador...

ENTREVISTADO 9: Computador.

Ana Beatriz: E o que você mais leva em consideração no momento da compra?

ENTREVISTADO 9: Acho que preço mesmo.

Ana Beatriz: E você já desistiu de alguma compra de livros online? ENTREVISTADO 9: Não... Quando eu entro geralmente para comprar online, eu sempre vou com o livro muito definido, então eu nunca cheguei a desistir de nenhum não. Eu passei a comprar online tem pouco tempo também, ano passado foi a primeira vez, então digamos que a minha história não é muito longa de compras na Amazon sabe? 
Ana Beatriz: Ah, então beleza! Acabou!

\section{ENTREVISTADO 10}

Ana Beatriz: Comecei a gravar já, tá bom?

ENTREVISTADO 10: Tá bom!

Ana Beatriz: Então para começar, em um ano, quantos livros em média você compra?

ENTREVISTADO 10: Bastante, mais de 20. Inclui digital né?

Ana Beatriz: Inclui sim!

ENTREVISTADO 10: Então 20 mesmo! Físicos são uns 10, mas com digital vai pra 20.

Ana Beatriz: E quantos desses são livros de romance?

ENTREVISTADO 10: A maioria, eu diria que $80 \%$.

Ana Beatriz: Em que formato você prefere ler? Físico, digital....

ENTREVISTADO 10: Então antigamente eu preferia físico, era muito relutante ao livro digital. Mas no ano passado, mais ou menos no meio do ano eu comprei um Kindle, pela questão do espaço, que eu já não tinha mais onde colocar livro. Ai eu me viciei no Kindle, hoje em dia eu acho muito mais confortável. Mas ainda assim, se fosse para escolher, eu acho que escolheria o físico.

Ana Beatriz: E por quê?

ENTREVISTADO 10: Pela aquela coisa de pegar no livro, sentir as páginas, o cheirinho de livro novo... Bem aquela coisa de pessoa que gosta de livro de romance.

Ana Beatriz: Bom, sabemos que você compra livros físicos através de canais digitais. Por que você faz dessa forma? Quais os benefícios que te fazem escolher esse canal para as suas compras? ENTREVISTADO 10: Olha, eu compro praticamente só na Amazon, é muito difícil eu comprar em outro site... E assim, lógico, ir na livraria é muito bom, você escolher o livro e tal. Mas na Amazon eu já tenho a lista dos livros que eu quero, eu fico acompanhando preço, se está na promoção ou não, eu consigo ler uma resenha do livro para saber se é bom se é ruim, fora que a entrega é extremamente confiável e rápida. Mesmo se você não comprar com a entrega expressa, eu sei que em três, quatro dias o livro vai estar na minha casa. 
Ana Beatriz: Bom, quando você entra no site da Amazon, sua compra já está definida ou a decisão é feita por impulso?

ENTREVISTADO 10: Não, eu vou por impulso. Então, eu tenho a minha lista, né? Que nem eu te falei, então eu entro, vejo se algum dos que estão na minha lista está em promoção ou diminui o preço, ai eu acabo comprando... Ou às vezes, eu entro para comprar um só e acabo indo naqueles livros sugeridos e acabo comprando mais de um.

Ana Beatriz: E você faz pesquisas em outros marketplaces antes de comprar na Amazon e, se sim, o que você busca nessa pesquisa?

ENTREVISTADO 10: Faço, eu pesquiso preço de tudo, porque né? Eu quero comprar o mais barato.

Ana Beatriz: Com que frequência costuma comprar livros no site Amazon?

ENTREVISTADO 10: Olha, ano passado eu comprei bastante. Eu diria que a cada um, dois meses.

Ana Beatriz: Bom, a gente já falou um pouco sobre a Amazon, mas para você tem algum outro diferencial dela com relação aos outros sites e marketplaces?

ENTREVISTADO 10: Eu acho que o serviço deles. Antigamente eu comprava muito na Saraiva, mas eu não acho que a Saraiva tenha um atendimento ao cliente tão bom. Porque assim, a Amazon, qualquer problema que dá, eles entram em contato com você na hora e resolvem o problema, sabe? Você não tem dor de cabeça. Isso, para mim, como consumidor é muito importante, porque comprar na internet algumas vezes dá muita dor de cabeça.

Ana Beatriz: Quantos livros físicos de romance você comprou através da Amazon? Pensa no último ano, assim...

ENTREVISTADO 10: Ano passado foram uns 5.

Ana Beatriz: E por qual canal você prefere realizar suas compras na Amazon? Celular, Tablet, Computador...

ENTREVISTADO 10: Computador, porque como eu disse eu faço pesquisa, entro em outros sites...

Ana Beatriz: E o que você mais leva em consideração no momento da compra?

ENTREVISTADO 10: A história do livro.

Ana Beatriz: E você já desistiu de alguma compra de livros online? ENTREVISTADO 10: Já! 


\section{Ana Beatriz $\mathrm{O}$ que te fez desistir? \\ ENTREVISTADO 10: O preço.}

Ana Beatriz: E na Amazon? Você já desistiu de alguma compra de livros online?

ENTREVISTADO 10: Sim, sim. Como eu falei eu compro praticamente só lá.

Ana Beatriz: E o que te fez desistir da compra quando foi na Amazon?

ENTREVISTADO 10: O preço, sempre o preço. (Risos)

\section{ENTREVISTADO 11}

Ana Beatriz: Comecei a gravar, tá?

ENTREVISTADO 11: Ta bom!

Ana Beatriz: Queria te agradecer mais uma vez por participar... Muito obrigada!

ENTREVISTADO 11: Nada, o que eu puder ajudar...

Ana Beatriz: Vamos começar?

ENTREVISTADO 11: Vamos!

Ana Beatriz: Então lá vai... Em um ano, quantos livros em média você compra?

ENTREVISTADO 11: Eita, acho que... Ano passado acho que eu comprei uns 40 livros.

Ana Beatriz: E quantos desses são livros de romance?

ENTREVISTADO 11: Eu diria uns 30.

Ana Beatriz: Em que formato você prefere ler? Físico, digital....

ENTREVISTADO 11: Atualmente eu prefiro o formato digital, pelo Kindle. Mas eu ainda me forço a ler um pouco no físico. Mas hoje em dia, digital.

Ana Beatriz: E por quê?

ENTREVISTADO 11: Eu acho que a praticidade. O kindle tem essa questão do peso, e eu sinto que a minha leitura fica mais fluida quando eu leio nele. Eu estou ainda com dificuldade de me readaptar a leitura no livro físico. Acho que no Kindle você tem essa facilidade do peso, de ficar mais fácil de você levar para os lugares, então no início do ano passado, quando eu ainda ia para a faculdade, eu levava e ia lendo no metrô, já ia adiantando as minhas leituras. Então eu acho que essa é a questão, a praticidade, parece que você está lendo mais rápido... 
Ana Beatriz: Bom, sabemos que você compra livros físicos através de canais digitais.

ENTREVISTADO 11: Sim.

Ana Beatriz: Por que você faz dessa forma? Quais os benefícios que te fazem escolher esse canal para as suas compras?

ENTREVISTADO 11: Eu compro muito pela Amazon principalmente pelo preço. A Travessa e a Amazon são livrarias muito boas, só que a questão é que hoje em dia livros são artigos de luxo, são caros no Brasil, então aqui a gente tem essa questão de livros serem 50 reais, e prélançamentos serem 60, 70 reais. Então na livraria acaba sendo muito caro e na Amazon eles tem toda uma estrutura de empresa, que vende não só livros, que faz com eles consigam baratear um pouco os livros. Então, eu acho que é muito pelo valor e pela praticidade, né? Você não precisa sair de casa, muitas vezes você nem paga o frete, para ter produto entregue na sua porta. Na livraria você tem esse esforço de ir, pagar mais caro e tudo isso.

Ana Beatriz: Bom, quando você entra no site da Amazon, sua compra já está definida ou a decisão é feita por impulso?

ENTREVISTADO 11: Eu já sei o que eu quero.

Ana Beatriz: E você faz pesquisas em outros marketplaces antes de comprar na Amazon?

ENTREVISTADO 11: Não faço, eu só vou direto.

Ana Beatriz: Com que frequência costuma comprar livros no site Amazon?

ENTREVISTADO 11: Cara, então... Antigamente eu comprava de duas em duas semanas, mas hoje em dia.... Acho que uma vez ao mês mais ou menos hoje em dia.

Ana Beatriz: $O$ que te leva a consumir nesse marketplace? Assim, qual o diferencial da Amazon com relação a outros canais digitais que o leva a consumir nela?

ENTREVISTADO 11: Eu acho que é muito isso do valor e da segurança que eu sinto em comprar na Amazon. Eu sei que o livro vai chegar na minha casa, tudo direitinho e eu não vou precisar me estressar... Então é isso, essa segurança, que eu sinto também na livraria, porque eu pego meu livro e eu pago por aquele exato produto, mas em um preço melhor, sem precisar se deslocar... às vezes não tem uma livraria no seu bairro, por exemplo, no meu... Eu moro em Copacabana e a Saraiva que tinha 
fechou, então eu tenho que pegar um Uber, ir pra Botafogo... Muito mais fácil entrar na Amazon, que eu vou comprar, sei que vai chegar perfeito, sem problemas, em um valor mais barato e em dois dias no máximo, sabe? Ah e sem pagar frete, porque eu tenho Amazon Prime.

Ana Beatriz: Ah sim! Bom, e quantos livros físicos de romance você comprou através da Amazon?

ENTREVISTADO 11: Todos, então os 30 que eu falei, lembra? Todos eles... (Risos)

Ana Beatriz: E por qual canal você prefere realizar suas compras na Amazon? Celular, Tablet, Computador...

ENTREVISTADO 11: Celular, no aplicativo da Amazon mesmo...

Ana Beatriz: E o que você mais leva em consideração no momento da compra?

ENTREVISTADO 11: Não sei.... Acho que a praticidade, não é aquela coisa muito burocrática as compras na Amazon, sabe? Eu valorizo o muito o fato de eu saber que o site é seguro para eu colocar minhas informações e é muito rápido! Já tem todas as informações minhas salvas, eu só aperto em um botão e acabou...

Ana Beatriz: E você já desistiu de alguma compra de livros online?

ENTREVISTADO 11: Já!

Ana Beatriz $\mathrm{O}$ que te fez desistir?

ENTREVISTADO 11: O preço.

Ana Beatriz: E na Amazon? Você já desistiu de alguma compra de livros online e se sim, o que te fez desistir?

ENTREVISTADO 11: A mesma coisa, o preço. Aconteceu semana passada, eu ia comprar um livro em pré-lançamento, mas estava 70 reais na Amazon. Ai eu falei, nossa não vou pagar 70 reais em um livro, sendo que eu sei que em dois meses o preço vai diminuir com certeza.

Ana Beatriz: E é isso! Acabou!

\section{ENTREVISTADO 12}

Ana Beatriz: Bom, a gente está gravando agora, tudo bem?

ENTREVISTADO 12: Tudo bem!

Ana Beatriz: Antes da gente começar só me confirma a sua idade por favor?

ENTREVISTADO 12: Eu tenho 20 anos. 
Ana Beatriz: Ah beleza, só para eu colocar aqui na relação... Posso começar?

ENTREVISTADO 12: Pode!

Ana Beatriz: Bom, a primeira pergunta é: em um ano, quantos livros em média você compra?

ENTREVISTADO 12: Nossa... (Risos) Se você falasse ler ia ser mais fácil, mas comprar... Mas eu diria uns 40 livros por ano, mais ou menos.

Ana Beatriz: E quantos desses são livros de romance?

ENTREVISTADO 12: Ah, acho que mais da metade é de romance... Eu diria uns $60 \%$.

Ana Beatriz: Em que formato você prefere ler? Físico, digital.... E porquê?

ENTREVISTADO 12: Depende do dia né? (Risos) Mas normalmente físico, porque dá aquela sensação de que você está avançando mais do que no Kindle. Mas eu leio muito no Kindle também, principalmente a noite... A noite eu prefiro o Kindle por causa da luz. Então acaba que eu leio mais no Kindle, mas eu prefiro mesmo ler no papel, até pela parte sensorial mesmo de pegar no papel, virar a página, o cheiro...

Ana Beatriz: Bom, sabemos que você compra livros físicos através de canais digitais.

ENTREVISTADO 12: Sim.

Ana Beatriz: Por que você faz dessa forma? Quais os benefícios que te fazem escolher esse canal para as suas compras?

ENTREVISTADO 12: É, meio que eu comecei por causa da pandemia. Antes eu quase não comprava pela internet, eu sempre comprava nas livrarias, mas agora com a pandemia não teve muito jeito. E na Amazon tem também aquela coisa de você comprar e chegar super-rápido, tem umas mega promoções, então isso acaba influenciando... Capaz de quando a vida voltar mais ao normal eu continue comprando pela internet porque agora já meio que virou costume.

Ana Beatriz: Bom, quando você entra no site da Amazon, sua compra já está definida ou a decisão é feita por impulso?

ENTREVISTADO 12: Tem a minha lista de desejos, né? É que ela é tão grande que acaba sendo uma surpresa... (Risos) Às vezes ele está na minha lista, só que eu esqueci, e quando entra em promoção eu acabo comprando. Mas normalmente eu tento me controlar para comprar aquilo 
que eu já estou querendo tem um tempinho sabe? Mas, é aquilo, se tem uma promoção e um livro está em um preço bom, eu compro.

Ana Beatriz: E você faz pesquisas em outros marketplaces antes de comprar na Amazon?

ENTREVISTADO 12: Ah sim! Sempre fico comparando... Porque submarino, americanas sempre dá muito cupom, o que a Amazon não faz. Então às vezes vale mais a pena. Mas hoje em dia eu tenho comprado muito livro pela Shopee, usado mesmo... Porque lá o frete é grátis, e os livros são bem mais baratos, até porque são usados. Chegaram perfeitos, então tenho comprado mais e mais lá.

Ana Beatriz: E o que você busca nessa pesquisa?

ENTREVISTADO 12: Eu comparo o preço. Isso é o principal. Ai eu comapro as promoções que eu vejo em outros sites, tipo o submarino que tem umas que é tipo, você comprando dois livros tem um desconto, e às vezes compensa. Então eu comparo isso.

Ana Beatriz: Com que frequência costuma comprar livros no site Amazon?

ENTREVISTADO 12: Agora eu acho que eu to comprando tipo todo mês.

Ana Beatriz: $O$ que te leva a consumir nesse marketplace? Assim, qual o diferencial da Amazon com relação a outros canais digitais que o leva a consumir nela?

ENTREVISTADO 12: O frete grátis, porque eu tenho Amazon Prime. Então às vezes está mais caro que em outros sites, mas como eu não pago o frete acaba valendo mais a pena. Também chega muito rápido, dois, três dias no máximo e o livro já chega na minha casa. E o preço também. Normalmente lá eles têm um preço muito melhor do que outros lugares, né? Então acaba que eu sempre escolho a Amazon por esses motivos. Ah outra coisa legal de falar também é que eu acho o site da Amazon muito mais legal do que os outros sabe? Assim, de funcionabilidade que eu falo. A navegação é fácil, não fica travando... E tem a lista de desejos lá também. Acaba que fica tudo na mão já!

Ana Beatriz: Quantos livros físicos de romance você comprou através da Amazon? Pensa no último ano, assim...

ENTREVISTADO 12: Acho que uns 18 de 25 são da Amazon.

Ana Beatriz: E por qual canal você prefere realizar suas compras na Amazon? Celular, Tablet, Computador... 
ENTREVISTADO 12: Ah eu vou pelo computador, porque eu tenho eu tenho um aplicativo de casshback que eu só consigo ativar quando eu uso pelo computador, então acaba que eu uso muito o computador mesmo para comprar.

Ana Beatriz: E o que você mais leva em consideração no momento da compra?

ENTREVISTADO 12: O frete é muito importante. Uma coisa que me irrita é pagar frete caro. Às vezes o frete é o preço do livro sabe?

Ana Beatriz: Sei sim! E, bom, você já desistiu de alguma compra de livros online? E se sim, o que te fez desistir?

ENTREVISTADO 12: Ah sim, sempre! Eu direto coloco no carrinho e depois desisto. Geralmente o que me faz desistir é tipo, eu vou pensando se eu vou ler agora, se eu realmente quero esse livro... E também tem aquela questão do frete que eu já falei.

Ana Beatriz: E na Amazon? Você já desistiu de alguma compra de livros online?

ENTREVISTADO 12: Ah sim!

\section{Ana Beatriz: E o que te fez desistir?}

ENTREVISTADO 12: O da Amazon é sempre o motivo do bolso mesmo. Eu tenho uma extensão do Chrome que eu consigo ver o histórico de preço daquele produto, para eu ver se realmente está valendo a pena. Então eu me guio por esses valores, e também... Assim, eu vejo se eu já comprei muito aquele mês, aí eu evito comprar mais, para não pesar. Eu vou estabelecendo limites, sabe? Então se está chegando perto eu procuro me controlar.

\section{ENTREVISTADO 13}

Ana Beatriz: Isa, comecei a gravar, tudo bem?

ENTREVISTADO 13: Tudo!

Ana Beatriz: Posso começar?

ENTREVISTADO 13: Pode sim!

Ana Beatriz: Então, primeira pergunta... Em um ano, quantos livros em média você compra?

ENTREVISTADO 13: Ah eu acho que uns 50.

Ana Beatriz: E quantos desses são livros de romance?

ENTREVISTADO 13: É... Uns 30. 
Ana Beatriz: Em que formato você prefere ler? Físico, digital....

ENTREVISTADO 13: Eu prefiro físico, mas hoje em dia eu tenho lido mais digital, porque eu gosto de ler em inglês e o dólar tá muito caro. Aí acaba que eu leio mais pelo Kindle, eu também tenho o Kindle Unlimited...

\section{Ana Beatriz: E por quê?}

ENTREVISTADO 13: Bom, eu tenho o Kindle mesmo, o aparelho, mas acaba que eu leio muito mais pelo Kindle do celular, e eu acho que isso é ruim, porque acaba cansando a vista, você recebe várias notificações e se distrai da leitura... E eu acho que o físico, você consegue se concentrar melhor, você consegue entrar mais na história... Sem contar o cheirinho de livro novo. Então eu prefiro o físico por isso, por não cansar tanto a vista e por eu conseguir me concentrar melhor.

Ana Beatriz: Bom, sabemos que você compra livros físicos através de canais digitais.

ENTREVISTADO 13: Sim.

Ana Beatriz: Por que você faz dessa forma? Quais os benefícios que te fazem escolher esse canal para as suas compras?

ENTREVISTADO 13: Então, na Amazon você compra com um clique só. Acaba que eu compro praticamente só lá e chega muito rápido. $E$ eu tenho Amazon Prime, né? Que ai eu tenho frete grátis. Eu não compro só pela internet, mas acaba que... digamos, de 50 livros que eu compro 40 são pela internet.

Ana Beatriz: Bom, quando você entra no site da Amazon, sua compra já está definida ou a decisão é feita por impulso?

ENTREVISTADO 13: Impulso! (Risos) Não quer dizer que eu não vou ler, porque eu leio tudo o que eu compro, mas é tipo, eu to com muita vontade, é muito fácil... Ai acaba que eu compro.

Ana Beatriz: E você faz pesquisas em outros marketplaces antes de comprar na Amazon?

ENTREVISTADO 13: Não, na realidade, quando eu estou em outros lugares, eu olho na Amazon e ai eu fico considerando se eu compro na hora, ou se eu espero a entrega. Mas quando eu entro na Amazon eu não procuro em outros lugares não.

Ana Beatriz: E nesses casos de você estar em outro lugar e entrar na Amazon, você procura o que?

ENTREVISTADO 13: Preço. 
Ana Beatriz: Com que frequência costuma comprar livros no site Amazon?

ENTREVISTADO 13: Assim, bem frequente... Eu compro mais ou menos a cada duas semanas.

Ana Beatriz: $O$ que te leva a consumir nesse marketplace? Assim, qual o diferencial da Amazon com relação a outros canais digitais que o leva a consumir nela?

ENTREVISTADO 13: Então, eu leio muito em inglês, então para mim esse é o diferencial da Amazon. O fato de que se eu comprar um livro em inglês que eu quero físico, ele vai chegar aqui em ótima qualidade, rápido e o preço... Chega aser triste, porque eu gosto muito de livraria, mas é muito competitivo.

Ana Beatriz: Quantos livros físicos de romance você comprou através da Amazon? Pensa no último ano, assim...

ENTREVISTADO 13: Eu só compro romance na Amazon, então acho que uns 30 mesmo.

Ana Beatriz: E por qual canal você prefere realizar suas compras na Amazon? Celular, Tablet, Computador...

ENTREVISTADO 13: Celular, app!

Ana Beatriz: E o que você mais leva em consideração no momento da compra?

ENTREVISTADO 13: Acho que o preço.

Ana Beatriz: E você já desistiu de alguma compra de livros online? ENTREVISTADO 13: Sim, já desisti.

Ana Beatriz $\mathrm{O}$ que te fez desistir?

ENTREVISTADO 13: Tinham alguns livros que quando eu ficava na dúvida eu ia perguntar para as minhas amigas se elas tinham gostado, e algumas vezes, quando elas falam que não, eu desistia da compra.

Ana Beatriz: E na Amazon? Você já desistiu de alguma compra de livros online?

ENTREVISTADO 13: Já também!

Ana Beatriz: $E$ o que te fez desistir?

ENTREVISTADO 13: Na Amazon, geralmente é isso que eu falei também. Mas uma vez, aconteceu uma coisa assim, muito atípica, que foi que o meu produto foi extraviado ou roubado, não lembro. Ai já tinha demorado muito para eu e eles nos darmos conta disso e ainda ia demorar mais algum tempo para o novo produto ser entregue. Ai eu 
acabei desistindo da compra. Mas essa foi uma situação muito pontual, que aconteceu só uma vez.

\section{ENTREVISTADO 14}

Ana Beatriz: Bom, a gente está gravando agora, tudo bem?

ENTREVISTADO 14: Beleza!

Ana Beatriz: Posso começar?

ENTREVISTADO 14: Pode claro!

Ana Beatriz: Então lá vai... Em um ano, quantos livros em média você compra?

ENTREVISTADO 14: Difícil essa... Ano passado eu comprei muitos e muitos livros. Eu diria que eu comprei uns 45 livros.

\section{Ana Beatriz: E quantos desses são livros de romance?}

ENTREVISTADO 14: Um pouquinho mais de 50\% total... Então de 45 que eu falei, acho que uns 25.

Ana Beatriz: Em que formato você prefere ler? Físico, digital....

ENTREVISTADO 14: Eu gosto muito de ler no físico. Hoje em dia eu estou ficando mais adepto ao Kindle, nesse ano principalmente, mas eu ainda prefiro ler no físico. Nesse último ano eu também comecei a escutar áudio livro... Mas para mim funciona como um complemento da leitura que eu faço normal, no livro digital ou físico. Então se eu quero continuar aquela leitura naquele dia, mas por exemplo é dia de faxina, eu sei que não vou conseguir ler, eu coloco o áudio livro para escutar.

Ana Beatriz: Ah que legal! Mas sobre o livro físico, por que você prefere ele?

ENTREVISTADO 14: Bom, tem alguns que eu prefiro ler no físico por questões estéticas. Então por exemplo, Agakê. Nesse caso o digital não funciona, porque eu acho que a agakê tem muito do material que eles usam pra imprimir os quadrinhos, da edição também, se ela é capa dura, se... Tem todo um trabalho que eu acho que no Kindle perde. Até porque no Kindle às vezes o quadrinho fica muito pequeno e você acaba não conseguindo ler. As leituras mais teóricas que eu faço para a faculdade, eu procuro fazer pelo Kindle. Então eu compro direto pelo Kindle e leio nele. Quando eu sinto que eu não vou gostar tanto do livro, sabe? Quando você lê a sinopse e enfim... Ou aquele livro que você lê meio de teste e se eu não gostar vai ficar aqui rolando em casa... Ai enfim, posso 
passar para a frente mas sempre é um "trâmitezinho" que eu prefiro evitar.

Ana Beatriz: Bom, sabemos que você compra livros físicos através de canais digitais.

ENTREVISTADO 14: Sim.

Ana Beatriz: Por que você faz dessa forma? Quais os benefícios que te fazem escolher esse canal para as suas compras?

ENTREVISTADO 14: No momento é não sair de cassa. Falando assim numa perspectiva geral, todo mundo começou a consumir mais na internet no ano passado. Então eu ia muito em livrarias mesmo e gostava muito de ir nos sebos do centro antes da pandemia. Com a pandemia, eu não pude mais fazer isso... Desde o ano passado eu não faço mais isso. É... comprar pela internet acaba suprindo essa minha "necessidade" de ir atualizando minha estante. Para mim o diferencial com relação ao físico é eu conseguir fazer uma comparação de preços, ser fácil de eu conseguir dar aquela comparada básica. Tem uns aplicativos que fazem isso, eu acho. Online também tem a questão da comodidade. Então eu estou a uma aba de distância de procurar cupons de desconto. Tem essa questão também. E eu acho que quando a gente compra com frequência, por exemplo, na Amazon, a gente sabe que é confiável. Claro que presencialmente, você sabe o que está levando, mas também tem essa questão de nunca ter dado problema nenhum. Se acontecer também eu sei que vai ser mega tranquilo de resolver. Eu já tive questões com entregas errado e eles resolveram mega rápido. Deu sempre tudo muito certo, eu nunca tive um problema com compra online.

Ana Beatriz: Bom, quando você entra no site da Amazon, sua compra já está definida ou a decisão é feita por impulso?

ENTREVISTADO 14: Ah quando eu vou comprar? Normalmente é uma coisa mais definida. É bem difícil eu ficar navegando procurando algo para comprar. Voltando um pouco para a pergunta anterior, isso é algo que o digital promove né? Quando você vai na livraria, você dá aquela voltinha, tem toda aquela experiência de você andar entre as estantes, olhar os livros, olhar as contracapas, as orelhas, enfim.... Enquanto no digital você não tem isso né? É normalmente mais direto.... A não ser que você vá dar uma olhada nas promoções do dia, mas se não ela é mais direta que a presencial. 
Ana Beatriz: E você faz pesquisas em outros marketplaces antes de comprar na Amazon?

ENTREVISTADO 14: Sim, sim! Eu sempre dou uma olhada no site da própria editora, mando e-mail e procuro ver se eles têm algum cupom disponível para compras no próprio site delas. Isso porque eu sei que enfim, na Amazon eles não ganham tanto, então eu tento priorizar. Mas assim, às vezes o valor é muito alto, fica impraticável. Mas eu olho também em sebos online, tipo Enjoei, Estante Virtual e Shopee. Na Shopee sempre tem uns cupons de frete grátis e tal. Mas ai eu faço principalmente esse caminho... Primeiro no site da editora, depois nos sebos e por último na Amazon para ver como está o preço lá.

Ana Beatriz: Ah legal! E o que você busca nessa pesquisa?

ENTREVISTADO 14: Preço e disponibilidade.

Ana Beatriz: Com que frequência costuma comprar livros no site Amazon?

ENTREVISTADO 14: Olha, agora, esse ano, tá uma coisa de uma vez por mês... No máximo duas vezes por mês. Eu e um grupo de amigos decidimos fazer um clube de leitura, então muitas vezes são livros que eu não tenho... Ai eu acabo comprando na Amazon uma vez por mês.

Ana Beatriz: $O$ que te leva a consumir nesse marketplace? Assim, qual o diferencial da Amazon com relação a outros canais digitais que o leva a consumir nela?

ENTREVISTADO 14: Principalmente, não tem como a gente negar isso, o preço. A gente sabe porque o preço é do jeito que é, mas é muito apelativo para um estagiário, com um salário baixo, ver os livros naquele valor e não querer que eles comprem, sabe? Então primeiramente o preço. Depois a assinatura do Amazon Prime, a minha família assina, então tem o frete grátis. E por úlitmo, a certeza de que vai chegar aqui em no máximo, assim, estourando muito, no máximo cinco dias. Então chega rápido e chega tudo certinho, sem nenhum problema.

Ana Beatriz: Quantos livros físicos de romance você comprou através da Amazon? Pensa no último ano, assim...

ENTREVISTADO 14: Pensando na média assim, acho que dá para pensar em uns 15.

Ana Beatriz: E por qual canal você prefere realizar suas compras na Amazon? Celular, Tablet, Computador...

ENTREVISTADO 14: Celular. 
Ana Beatriz: E o que você mais leva em consideração no momento da compra?

ENTREVISTADO 14: Na hora de finalizar? Bom o quanto que eu quero aquele livro naquele momento, se o preço está bom, porque a gente sabe que a Amazon sempre tem umas promoções meio relâmpago, então às vezes eu consigo esperar o livro dar uma abaixada, e.... Acho que é isso, o quanto que eu quero e o preço.

Ana Beatriz: E você já desistiu de alguma compra de livros online? ENTREVISTADO 14: Ah sim!

Ana Beatriz $\mathrm{O}$ que te fez desistir?

ENTREVISTADO 14: Realmente isso de repensar, de colocar as coisas no carrinho e.... Ano passado no Amazon Day, eu enchi meu carrinho de coisa e eu fiquei o dia inteiro pensando se eu realmente queria aqueles livros ou não. Ai eu enchi para pegar o desconto, fiquei pensando, pensando, pensando e no final, eu fiquei só com dois livros. No início eu tinha 7. Mas é isso, de repensar o que eu to comprando.

Ana Beatriz: E na Amazon? Você já desistiu de alguma compra de livros online?

ENTREVISTADO 14: Sim sim!

Ana Beatriz: E o que te fez desistir das compras lá?

ENTREVISTADO 14: A mesma coisa, isso de ponderar sobre o que eu estou comprando.

\section{ENTREVISTADO 15}

Ana Beatriz: Bom, comecei a gravar....

ENTREVISTADO 15: Uhum

Ana Beatriz: Posso começar?

ENTREVISTADO 15: Claro!

Ana Beatriz: Bom, primeira pergunta... Em um ano, quantos livros em média você compra?

ENTREVISTADO 15: (Risos) Nossa já começa assim? Olha... Entre 30 e 40.

Ana Beatriz: E quantos desses são livros de romance?

ENTREVISTADO 15: Muitos, assim... eu diria que $90 \%$.

Ana Beatriz: Em que formato você prefere ler? Físico, digital.... ENTREVISTADO 15: Prefiro físico. 
Ana Beatriz: E por quê?

ENTREVISTADO 15: Apego emocional. (Risos) Eu tenho o Kindle, mas eu amo ter o livro na mão, para poder marcar, escrever... Mas praticidade do digital é inegável.

Ana Beatriz: Bom, sabemos que você compra livros físicos através de canais digitais. Por que você faz dessa forma? Quais os benefícios que te fazem escolher esse canal para as suas compras? ENTREVISTADO 15: Preço. Infelizmente a gente tem que falar isso. Gostaria de poder comprar só em livrarias físicas, mas o preço é muito diferente... E o conforto, né? Chega aqui em casa muito rápido, morando no Rio em dois, três dias chega... O cartão de crédito já está cadastrado... Você não precisa se esforçar muito.

Ana Beatriz: Sim, E quando você entra no site da Amazon, sua compra já está definida ou a decisão é feita por impulso?

ENTREVISTADO 15: Geralmente tem vários grupos de promoção e eu já entro ali e compro, sem nem saber direito que livro é. (Risos)

Ana Beatriz: E você faz pesquisas em outros marketplaces antes de comprar na Amazon?

ENTREVISTADO 15: Sim. Eu geralmente olho nas Lojas Americanas e no Submarino.

Ana Beatriz: E o que você busca nessa pesquisa?

ENTREVISTADO 15: Preço e também frete.

Ana Beatriz: Com que frequência costuma comprar livros no site Amazon?

ENTREVISTADO 15: De 15 em 15 dias mais ou menos.

Ana Beatriz: $O$ que te leva a consumir nesse marketplace? Assim, qual o diferencial da Amazon com relação a outros canais digitais que o leva a consumir nela?

ENTREVISTADO 15: Preço e rapidez de entrega. Eles são bizarros.

Ana Beatriz: Quantos livros físicos de romance você comprou através da Amazon? Pensa no último ano, assim...

ENTREVISTADO 15: Eu devo ter comprado uns 25 para mais.

Ana Beatriz: E por qual canal você prefere realizar suas compras na Amazon? Celular, Tablet, Computador...

ENTREVISTADO 15: Celular, geralmente eu compro pelo celular.

Ana Beatriz: E o que você mais leva em consideração no momento da compra? 
ENTREVISTADO 15: Preço geralmente.

Ana Beatriz: $E$ você já desistiu de alguma compra de livros online?

ENTREVISTADO 15: Já! Já cancelei.

Ana Beatriz: $\mathrm{E}$ o que te fez desistir?

ENTREVISTADO 15: Eu pensei melhor. (Risos) Eu desisto quando tem alguma promoção muito bombástica, e aí 10 minutos depois eu vejo que eu não vou ler esse livro tão cedo... Então eu cancelo. Já aconteceu.

Ana Beatriz: E na Amazon? Você já desistiu de alguma compra de livros online?

ENTREVISTADO 15: Já.

Ana Beatriz: $E$ o que te fez desistir?

ENTREVISTADO 15: Ah, mesma coisa. Fui pensar, e vi que eu ia comprar só por impulso... Ai eu cancelo.

\section{ENTREVISTADO 16}

Ana Beatriz: Bom, amiga, comecei a gravar aqui, beleza?

ENTREVISTADO 16: Ok!

Ana Beatriz: Então vamos lá para a primeira pergunta... Em um ano, quantos livros em média você compra?

ENTREVISTADO 16: Olha, nesse último ano eu comprei uns 10 livros.

Ana Beatriz: E quantos desses são livros de romance?

ENTREVISTADO 16: Quatro! O resto foi livro para a faculdade...

Ana Beatriz: Em que formato você prefere ler? Físico, digital.... ENTREVISTADO 16: Físico.

Ana Beatriz: E por quê?

ENTREVISTADO 16: Não gosto de ler livro digital. Não sei, eu sou uma pessoa meio analógica, eu gosto de ter as coisas na mão. As pessoas sempre me falaram, por exemplo, que pra fazer medicina você tinha que se adaptar ao digital, que era muita coisa e tal... Eu não acreditei, não achava também que eu ia conseguir, porque eu gosto disso, do papel, de folhear... Mas realmente eu não estou dando conta, preciso me adaptar. Mas livro, eu gosto de pegar, marcar, escrever, não sei...

Ana Beatriz: Bom, sabemos que você compra livros físicos através de canais digitais. Por que você faz dessa forma? Quais os benefícios que te fazem escolher esse canal para as suas compras? ENTREVISTADO 16: Eu acho mais prático. Assim, eu quero um livro. Eu vou sair de casa, para ir no shopping, para ir na livraria, sabe? Se eu 
quero um livro, eu busco na internet rapidinho, vejo lá e compro. Mais prático, mais rápido. Por mais que demore para chegar... Se bem que hoje em dia chega muito rápido. E na Amazon, eu tenho Prime, então não tem frete na maioria das vezes.

Ana Beatriz: Bom, quando você entra no site da Amazon, sua compra já está definida ou a decisão é feita por impulso?

ENTREVISTADO 16: Sim, eu já tenho uma definida... Sempre é tipo, me recomendaram o livro tal, ai eu entro da internet e compro.

Ana Beatriz: E você faz pesquisas em outros marketplaces antes de comprar na Amazon?

ENTREVISTADO 16: Faço. Geralmente, quando eu vou pesquisar um livro, eu coloco direto no Google. Eu não vou direto na Amazon procurar o livro, porque eu sei que o Google vai me dar as melhores opções e ai dentre as opções que o Google me dá, na maioria das vezes a que tem o melhor preço é a Amazon e a Americanas. Esses são os sites que aparecem.

Ana Beatriz: E o que você busca nessa pesquisa?

ENTREVISTADO 16: Eu procuro o melhor preço.

Ana Beatriz: Com que frequência costuma comprar livros no site Amazon?

ENTREVISTADO 16: Olha, eu não tenho uma frequência certa. Quando eu quero muito um livro ou quando eu estou precisando muito mesmo, que foi o caso dos livros da faculdade, eu entro e compro. Mas uma frequência? Eu não tenho muita... Mas pelo menos umas duas, três vezes por ano eu compro.

Ana Beatriz: 0 que te leva a consumir nesse marketplace? Assim, qual o diferencial da Amazon com relação a outros canais digitais que o leva a consumir nela?

ENTREVISTADO 16: Ah a Amazon geralmente tem o melhor preço né? Fora isso, eu tenho o Amazon Prime, que faz com que na maioria das vezes eu não tenha que pagar frete... Porque tem vezes que, tipo a Americanas tem um preço melhor, mas com o frete, fica mais caro do que na Amazon, então isso influencia muito sabe? E também... Assim, a certeza que vai chegar tudo certo, sabe? A confiança que a gente tem na empresa... Acho que é isso.

Ana Beatriz: Quantos livros físicos de romance você comprou através da Amazon? Pensa no último ano, assim... 
ENTREVISTADO 16: Comprei dois.

Ana Beatriz: E por qual canal você prefere realizar suas compras na Amazon? Celular, Tablet, Computador...

ENTREVISTADO 16: Computador.

Ana Beatriz: E o que você mais leva em consideração no momento da compra?

ENTREVISTADO 16: Preço.

Ana Beatriz: E você já desistiu de alguma compra de livros online? ENTREVISTADO 16: Já!

Ana Beatriz $O$ que te fez desistir?

ENTREVISTADO 16: Assim, eu desisti naquele momento, mas depois comprei o livro. Fiquei pesquisando, pesquisando, porque esses livros de anatomia são caros. Al fiquei pensando em comprar com o meu cartão e parcelar, ai depois pensei em pedir para os meus pais.... Foi mais isso, de ficar namorando o livro.

Ana Beatriz: E na Amazon? Você já desistiu de alguma compra de livros online?

ENTREVISTADO 16: Já, já!

Ana Beatriz: $E$ o que te fez desistir?

ENTREVISTADO 16: Ah geralmente o que me faz desistir é a grana mesmo, sabe? Então esse mesmo motivo....

\section{ENTREVISTADO 17}

Ana Beatriz: Bom, a gente está gravando agora... Posso começar?

ENTREVISTADO 17: Aham, vamos lá!

Ana Beatriz: Então lá vai... Em um ano, quantos livros em média você compra?

ENTREVISTADO 17: Hum... Assim, fazendo uma estimativa, talvez uns 15 livros.

Ana Beatriz: E quantos desses são livros de romance?

ENTREVISTADO 17: Eu diria que a grande maioria... Dos 15, talvez 12 sejam de romance.

Ana Beatriz: Em que formato você prefere ler? Físico, digital....

ENTREVISTADO 17: Olha, atualmente... Eu comprei o Kindle, né? Recentemente... Então eu estou gostando bastante de ler nele. Então nesse momento eu acho que eu prefiro digital.

Ana Beatriz: E por quê? 
ENTREVISTADO 17: Eu acho mais prático, mais confortável, eu acho que o estilo digital me estimula mais a ler assim... A coisa do Kindle ter a porcentagem do livro que você já leu... Faz com que você queria ler muito mais, sabe?

Ana Beatriz: Sei, sei. Bom, você compra livros físicos através de canais digitais, né? A gente sabe.

ENTREVISTADO 17: Isso.

Ana Beatriz: Por que você faz dessa forma? Quais os benefícios que te fazem escolher esse canal para as suas compras?

ENTREVISTADO 17: Principalmente o preço. Assim, eu adoro ir em livraria, adoro ficar vendo os livros e tal, e adoraria comprar mais em livrarias. Mas realmente, o site, a Amazon, tem preços muito baratos. Então acaba que eu dou preferência a eles.

Ana Beatriz: E quando você entra no site da Amazon, sua compra já está definida ou a decisão é feita por impulso?

ENTREVISTADO 17: Não, geralmente quando eu entro no site para comprar eu já tenho o livro específico que eu quero. O que eu faço é que normalmente eu vou na livraria, e ali eu procuro livros novos, e se eu me interesso por um livro ali eu vejo o preço e comparo com o da internet. $\mathrm{Na}$ maioria das vezes eu opto pelo da internet.

Ana Beatriz: E você faz pesquisas em outros marketplaces antes de comprar na Amazon?

ENTREVISTADO 17: Ah sim, às vezes sim. Às vezes eu vou na Submarino, às vezes nas Lojas Americanas... Mas eu geralmente começo pela Amazon e é por lá que eu compro mesmo.

Ana Beatriz: E o que você busca nessa pesquisa?

ENTREVISTADO 17: Ver o preço, né? O preço do livro, o preço do frete... Ver qual está mais em conta.

Ana Beatriz: Com que frequência costuma comprar livros no site Amazon?

ENTREVISTADO 17: Ah, diria que assim... Talvez eu compre um livro por mês, mais ou menos. Então mensalmente.

Ana Beatriz: 0 que te leva a consumir nesse marketplace? Assim, qual o diferencial da Amazon com relação a outros canais digitais que o leva a consumir nela?

ENTREVISTADO 17: Então, eu não conheço muito outros sites que tenham assim uma variedade tão grande de produtos... É, eu não 
conhecia também a Amazon até uns dois atrás... Foi minha namorada que me mostrou a Amazon e eu achei muito legal, porque tem muitas coisas e assim... A Amazon tem uma facilidade de custo muito grande, né? O site é fácil de entender, fácil de pesquisar, os preços também são uma grande vantagem... Não sei como, mas eles conseguem fazer os preços ficarem muito baixos para uma série de coisas, talvez por serem uma empresa tão grande, né? Então eu acho que é isso, o preço, po preço do frete também geralmente não é muito caro, e a facilidade de mexer... E é o site que eu conheço, não conheço muitos outros.

Ana Beatriz: E quantos livros físicos de romance você comprou através da Amazon? Pensa no último ano, assim...

ENTREVISTADO 17: Nesse último ano... Talvez eu tenha comprado uns 10 dos 12 que eu falei.

Ana Beatriz: E por qual canal você prefere realizar suas compras na Amazon? Celular, Tablet, Computador...

ENTREVISTADO 17: Geralmente, eu vou pelo computador, prefiro.

Ana Beatriz: E o que você mais leva em consideração no momento da compra?

ENTREVISTADO 17: Eu acho que o preço mesmo.

Ana Beatriz: E você já desistiu de alguma compra de livros online? ENTREVISTADO 17: Desistir?

Ana Beatriz: Isso! Não só na Amazon, mas em outros sites também. ENTREVISTADO 17: Ah que eu me lembre não... Eu pesquiso muito antes de comprar, então isso eu faço. Mas desistir, eu acho que não.

Ana Beatriz: Ah então beleza! Foi isso!

\section{ENTREVISTADO 18}

Ana Beatriz: Bom, comcei a gravar aqui e já vou começar, tudo bem?

ENTREVISTADO 18: Claro, vamos!

Ana Beatriz: Então lá vai... Em um ano, quantos livros em média você compra?

ENTREVISTADO 18: Nossa, calma... Eu acho que ano passado foram uns 10 livros mais ou menos.

Ana Beatriz: E quantos desses são livros de romance?

ENTREVISTADO 18: Ah, pouco. Eu diria que talvez um terço. Então de 10, uns 3. Eu gosto de ler livros teóricos. 
Ana Beatriz: Em que formato você prefere ler? Físico, digital.... ENTREVISTADO 18: Físico.

Ana Beatriz: E por quê?

ENTREVISTADO 18: Porque eu gosto de livro... Eu não sei explicar direito, mas eu gosto muito de mídias físicas. Eu gosto de CD também. Eu acho que aquele é o estágio primário daquilo ali sabe? E eu sinto mais conforto também... Mesmo que seja em um aparelho específico para isso, eu não gosto e muita gente não gosta por causa de claridade e tal. Então mesmo em aparelhos específicos, tipo o Kindle, eu não gosto, eu prefiro o físico mesmo.

Ana Beatriz: Bom, sabemos que você compra livros físicos através de canais digitais.

ENTREVISTADO 18: Sim.

Ana Beatriz: Por que você faz dessa forma? Quais os benefícios que te fazem escolher esse canal para as suas compras?

ENTREVISTADO 18: A vantagem eu diria que é a praticidade. De você fazer uma compra rápida... Quem compra ebook tem ele ali na hora. Então é isso, a praticidade.

Ana Beatriz: Bom, quando você entra no site da Amazon, sua compra já está definida ou a decisão é feita por impulso?

ENTREVISTADO 18: Eu já tenho a compra definida.

Ana Beatriz: E você faz pesquisas em outros marketplaces antes de comprar na Amazon?

ENTREVISTADO 18: Depende, mas é geralmente eu confio na Amazon. Mas dependendo do livro gosto de pesquisar... Quando é uma coisa muito específica eu tendo a confiar bastante na Amazon até porque não aparecem outras buscas.

Ana Beatriz: E o que você busca nessa pesquisa?

ENTREVISTADO 18: Preço. Quando eu vou comprar livros físicos eu vejo a edição também, mas o preço eu diria que é o fator que fala mais alto.

Ana Beatriz: Com que frequência costuma comprar livros no site Amazon?

ENTREVISTADO 18: Baixa. Assim no máximo a 5. Eu compro mais livro presencial, mas agora com a pandemia eu tenho comprado mais online mesmo. Mas eu diria umas 5 vezes mesmo. 
Ana Beatriz: 0 que te leva a consumir nesse marketplace? Assim, qual o diferencial da Amazon com relação a outros canais digitais que o leva a consumir nela?

ENTREVISTADO 18: É.. A referência, o nome da empresa e tudo mais. E compras passadas que deram certo assim.

Ana Beatriz: Quantos livros físicos de romance você comprou através da Amazon? Pensa no último ano, assim...

ENTREVISTADO 18: Acho que eu comprei um... Mas é muito pouco, até abri aqui para ver (Risos).

Ana Beatriz: E por qual canal você prefere realizar suas compras na Amazon? Celular, Tablet, Computador...

ENTREVISTADO 18: Computador.

Ana Beatriz: E o que você mais leva em consideração no momento da compra?

ENTREVISTADO 18: Se a empresa é séria. Se a empresa é confiável, se tem uma referência... Se eu não vou ter nenhum tipo de problema com o produto, sabe?

Ana Beatriz: Sei, sei. E você já desistiu de alguma compra de livros online?

ENTREVISTADO 18: Sim.

Ana Beatriz $\mathrm{O}$ que te fez desistir?

ENTREVISTADO 18: Por economia. Não necessariamente porque estava caro, mas por economia mesmo. Botei no carrinho e não dava... Desisti de comprar porque eu estou mais apertada...

Ana Beatriz: E na Amazon? Você já desistiu de alguma compra de livros online?

ENTREVISTADO 18: Já também!

Ana Beatriz: $E$ o que te fez desistir?

ENTREVISTADO 18: O mesmo motivo... Essa coisa de pensar melhor e perceber que ia ficar pesado para mim naquele mês... Enfim.

Ana Beatriz: E é isso... Acabou!

\section{ENTREVISTADO 19}

Ana Beatriz: Bom Lu, comecei a gravar aqui, tudo bem?

ENTREVISTADO 19: Tudo certo!

Ana Beatriz: Posso começar?

ENTREVISTADO 19: Pode, pode sim! 
Ana Beatriz: Então primeira pergunta... Em um ano, quantos livros em média você compra?

ENTREVISTADO 19: Hum.. Espera, deixa eu pensar... Vou colocar uma média de 10 por ano.

Ana Beatriz: E quantos desses são livros de romance?

ENTREVISTADO 19: Uns 3 ou 4.

Ana Beatriz: Em que formato você prefere ler? Físico, digital.... ENTREVISTADO 19: Físico.

\section{Ana Beatriz: E por quê?}

ENTREVISTADO 19: Porque me estimula mais a ler, eu gosto de guardar no meu quarto os livros que me marcam, eu gosto de ter esse estimulo visual de ter um tempo das minhas tecnologias e me sentir mais reclusa, fora desse mundo digital que a gente vive. Me dá mais a sensação de um tempo comigo mesma do que se estivesse com um Kindle, por exemplo, na mão.

Ana Beatriz: Bom, sabemos que você compra livros físicos através de canais digitais.

ENTREVISTADO 19: Sim.

Ana Beatriz: Por que você faz dessa forma? Quais os benefícios que te fazem escolher esse canal para as suas compras?

ENTREVISTADO 19: Bom, atualmente, por causa da pandemia, já que eu não estou saindo de casa. Mas normalmente, é muito prático, porque a Amazon tem um tempo de entrega muito rápido... Então eu compro e dois dias depois já está aqui. Então necessidade de eu me deslocar, sabe? Muitas vezes a gente fica sabendo de um livro legal na Internet, vê alguém recomendando e é muito simples... Você entra ali e em um clique você compra, e está feito. E o frete grátis, por causa da Amazon Prime, né?

Ana Beatriz: Bom, quando você entra no site da Amazon, sua compra já está definida ou a decisão é feita por impulso?

ENTREVISTADO 19: Então, eu normalmente entro com um na cabeça já... Só que eu acabo vendo as recomendações. Romance... A última vez que eu comprei romance online eu fui ver a lista das recomendações deles dos mais vendidos, e depois eu fui dar uma olhada na sinopse e resenha das pessoas na internet, então assim, como as pessoas estavam classificando. Mas quando eu vou comprar livros, assim, de assuntos que me interessam... Tipo sistema carcerário e tal, vem 
recomendações embaixo e acaba que vai uma coisa meio que em cadeia.

Ana Beatriz: E você faz pesquisas em outros marketplaces antes de comprar na Amazon?

ENTREVISTADO 19: Eu vou direto na Amazon, por causa da praticidade mesmo.

Ana Beatriz: Com que frequência costuma comprar livros no site Amazon?

ENTREVISTADO 19: Eu não tenho uma frequência muito específica não.

Eu compro mais quando eu tenho interesse... Romance eu compro quando eu sinto que eu preciso dar uma escapada da realidade. Então sempre que eu estou me sentindo mais sobrecarregada eu compro um livro novo. Até porque livro de romance eu leio muito rápido. Então eu leio rapidinho, e depois volto pra minha vida normal, minhas leituras mais pesadas e quando eu fico sobrecarregada de novo eu vou lá e compro.

Ana Beatriz: 0 que te leva a consumir nesse marketplace? Assim, qual o diferencial da Amazon com relação a outros canais digitais que o leva a consumir nela?

ENTREVISTADO 19: Então, o tempo de entrega. Eu acho o tempo de entrega deles muito bom, então principalmente isso. Eu também acho o site deles muito fácil de navegar, de achar as coisas, acho muito bemorganizado... Sempre que eu coloco alguma coisa lá pra procurar eu acho muito rápido, mas principalmente a rapidez da entrega mesmo.

Ana Beatriz: Quantos livros físicos de romance você comprou através da Amazon? Pensa no último ano, assim...

ENTREVISTADO 19: Então, eu comprei uns 4 no ano passado.

Ana Beatriz: E por qual canal você prefere realizar suas compras na Amazon? Celular, Tablet, Computador...

ENTREVISTADO 19: Compro no computador ou no celular, mas com mais frequência no celular.

Ana Beatriz: E o que você mais leva em consideração no momento da compra?

ENTREVISTADO 19: É... Preço e o tempo de entrega.

Ana Beatriz: E você já desistiu de alguma compra de livros online e se sim, o que te fez desistir?

ENTREVISTADO 19: Então, já desisti quando eu tinha que comprar algum livro didático pra faculdade sabe? Eram muito caros, tipo uns 120 
reais. Ai eu acabei não comprando o livro. Mas romance e esses livros que eu gosto geralmente são mais baratos, então eu sempre compro.

Ana Beatriz: E na Amazon? Você já desistiu de alguma compra de livros e se sim, o que te fez desisitir?

ENTREVISTADO 19: Ah, mesma coisa... Quando eu desisti foi lá. Então o preço do livro, sabe?

Ana Beatriz: Sei, sei! É isso, foi! Vou desligar aqui...

\section{ENTREVISTADO 20}

Ana Beatriz: ${ }^{\star \star \star \star}$ seguinte, comecei a gravar aqui, tudo bem?

ENTREVISTADO 20: Beleza!

Ana Beatriz: Posso começar?

ENTREVISTADO 20: Pode, pode sim!

Ana Beatriz: Então primeira pergunta... Em um ano, quantos livros em média você compra? Vamos considerar assim o ano passado...

ENTREVISTADO 20: Ano passado eu comprei poucos livros... Uns dois ou três livros. Mas antes eu comprava muitos livros. Porque antigamente eu gerava os boletos, então era mais fácil... Eu ia tranquilamente no banco ou em algum lugar pagar sem ter medo de pegar Corona né? Mas como hoje eu não tenho cartão e não saio de casa é meio que raridade comprar coisas virtuais.

Ana Beatriz: E quantos desses são livros de romance?

ENTREVISTADO 20: Todos. Eu só leio romance.

Ana Beatriz: Em que formato você prefere ler? Físico, digital....

ENTREVISTADO 20: Físico, mil vezes físico.

Ana Beatriz: E por quê?

ENTREVISTADO 20: Porque eu uso óculos, eu sinto que a minha vista fica muito cansada quando eu leio no formato digital. E eu amo aquele cheirinho de livro, de ter o livro ali, gosto de marcar o livro... Coisas que no digital eu não posso fazer.

Ana Beatriz: Bom, você compra livros físicos através de canais digitais.

ENTREVISTADO 20: Isso.

Ana Beatriz: Por que você faz dessa forma? Quais os benefícios que te fazem escolher esse canal para as suas compras? 
ENTREVISTADO 20: Pela praticidade de não ter que ir à livraria né? E também... Tipo, tem um livro que eu estava procurando muito nas livrarias físicas, sabe? E não achava de jeito nenhum! Até que uma amiga me falou, "ENTREVISTADO 20, porque você não procura na internet?" e isso me deu um estalo! Ai sim eu consegui achar o livro e ele chegou em menos de um mês... Então assim, pela praticidade e pela garantia de que eu vou achar aquilo que eu estou procurando.

Ana Beatriz: Bom, quando você entra no site da Amazon, sua compra já está definida ou a decisão é feita por impulso?

ENTREVISTADO 20: Eu geralmente entro já atrás de uma coisa... Mas eu fico vendo e fico tipo "Huum, esse parece ser legal também!". Aí vai aumentando a lista.

Ana Beatriz: E você faz pesquisas em outros marketplaces antes de comprar na Amazon?

ENTREVISTADO 20: Pesquiso sim!

Ana Beatriz: E o que você busca nessa pesquisa?

ENTREVISTADO 20: O preço e o tempo de entrega!

Ana Beatriz: Com que frequência costuma comprar livros no site Amazon?

ENTREVISTADO 20: Antes eu comprava muito, mas agora na pandemia eu comprei pouquíssimas vezes... Foi aquilo que eu te falei, eu imprimo boleto, porque eu não tenho cartão. Para eu ir no banco, me expor ao risco eu prefiro não comprar nada. Mas antes eu comprava quase que mensalmente, até porque eu ia para o estágio no metrô lendo, então precisava sempre de um livrinho novo.

Ana Beatriz: 0 que te leva a consumir nesse marketplace? Assim, qual o diferencial da Amazon com relação a outros canais digitais que o leva a consumir nela?

ENTREVISTADO 20: Cara, eu acho a entrega muito mais rápida que a da Saraiva, eu acho o site muito melhor do que o da Saraiva e o preço raramente tem uma grande diferença, em relação a Saraiva. A Amazon faz mais promoções eu acho... Eu acho a Saraiva muito cara.

Ana Beatriz: Quantos livros físicos de romance você comprou através da Amazon? Pensa no último ano, assim...

ENTREVISTADO 20: Todos os três.

Ana Beatriz: E por qual canal você prefere realizar suas compras na Amazon? Celular, Tablet, Computador... 
ENTREVISTADO 20: Pelo celular!

Ana Beatriz: $\mathrm{E}$ o que você mais leva em consideração no momento da compra?

ENTREVISTADO 20: Preço.

Ana Beatriz: $E$ você já desistiu de alguma compra de livros online? ENTREVISTADO 20: Ah já! Eu saio colocando tudo no meu carrinho. No final eu vou dar uma olhada e saio tirando. (Risos)

Ana Beatriz: $E$ o que te fez desistir?

ENTREVISTADO 20: A quantidade de livros que eu queria comprar. Eu ia priorizando os que eu estava mais animada para ler.

Ana Beatriz: E na Amazon? Você já desistiu de alguma compra de livros online e se sim, o que te fez desistir?

ENTREVISTADO 20: Eu só compro na Amazon, então minhas desistências foram lá mesmo! Então mesma resposta... A quantidade de livros que tinha no meu carrinho, então o preço final da compra.

\section{ENTREVISTADO 21}

Ana Beatriz: ${ }^{* * * *}$, comecei a gravar aqui, tudo bem?

ENTREVISTADO 21: Beleza!

Ana Beatriz: Vou começar então! Primeira pergunta... Em um ano, quantos livros em média você compra?

ENTREVISTADO 21: Total na Amazon?

Ana Beatriz: Tudo! Amazon, fora da Amazon, físico, digital...

ENTREVISTADO 21: Eu comprando, uns 15.

Ana Beatriz: $E$ quantos desses são livros de romance?

ENTREVISTADO 21: A maioria... Acho que todos na realidade.

Ana Beatriz: Em que formato você prefere ler? Físico, digital....

ENTREVISTADO 21: Fìsico. Nunca li nenhum livro digital.

Ana Beatriz: E por quê?

ENTREVISTADO 21: Pegar, né? Eu marco o livro, eu escrevo nele... Eu levo para qualquer lugar sem ter problema de bateria... O cheirinho de novo. Só por isso.

Ana Beatriz: Bom, sabemos que você compra livros físicos através de canais digitais.

ENTREVISTADO 21: Sim.

Ana Beatriz: Por que você faz dessa forma? Quais os benefícios que te fazem escolher esse canal para as suas compras? 
ENTREVISTADO 21: Eu acho que tem um acervo muito maior. Às vezes eu vou em livraria física, de bobeira e acabo comprando um. Mas geralmente, quando eu quero um livro eu entro na internet e já vou direto comprar o meu livro... Para não ter aquilo, fui na livraria comprar o livro e não tinha, fui na outra e também não tinha... Na internet eu acho que é mais certeiro. Então quando eu sei que livro eu quero eu vou direto lá.

Ana Beatriz: Bom, quando você entra no site da Amazon, sua compra já está definida ou a decisão é feita por impulso?

ENTREVISTADO 21: Geralmente está definida. A não ser que eu não tenha nenhum livro que eu queira ler no momento, ai eu dou uma olhada, mas na grande maioria das vezes ela já está definida.

Ana Beatriz: E você faz pesquisas em outros marketplaces antes de comprar na Amazon?

ENTREVISTADO 21: Não...

Ana Beatriz: Com que frequência costuma comprar livros no site Amazon?

ENTREVISTADO 21: Agora na pandemia eu estou comprando direto... Eu diria que mensalmente. Todos os livros que eu compro, eu compro por lá. Porque chega rápido, eu assinei aquele Amazon Prime e não pago frete... Então para mim é muito mais cômodo. E chega super-rápido, isso eu acho incrível. Eu compro e dois dias depois já está na minha porta.

Ana Beatriz: 0 que te leva a consumir nesse marketplace? Assim, qual o diferencial da Amazon com relação a outros canais digitais que o leva a consumir nela?

ENTREVISTADO 21: O frete grátis e a rapidez. Ah! E eles embalam o livro muito bem também... Eu já comprei em lugares onde o livro vem mal embalado, ai amassa a capa e tal. Na Amazon eles embalam direitinho.

Ana Beatriz: Quantos livros físicos de romance você comprou através da Amazon? Pensa no último ano, assim...

ENTREVISTADO 21: Ah gente, os 15. Todos.

Ana Beatriz: E por qual canal você prefere realizar suas compras na Amazon? Celular, Tablet, Computador...

ENTREVISTADO 21: Pelo app! Celular...

Ana Beatriz: E o que você mais leva em consideração no momento da compra?

ENTREVISTADO 21: Preço, frete e o número um é a rapidez da entrega... Se demorar muito eu cogito ir na livraria física. 
Ana Beatriz: E você já desistiu de alguma compra de livros online e se sim, o que te fez desistir?

ENTREVISTADO 21: Já! Por preço, frete, quando é o mesmo preço do livro.

Ana Beatriz: E na Amazon? Você já desistiu de alguma compra de livros online?

ENTREVISTADO 21: Na Amazon eu não me lembro de desistir... O frete é sempre ok, a entrega rápida...

\section{ENTREVISTADO 22}

Ana Beatriz: Só para te avisar, já comecei a gravar, ok?

ENTREVISTADO 22: Ok!

Ana Beatriz: Posso começar?

ENTREVISTADO 22: Pode sim!

Ana Beatriz: Então lá vai... Em um ano, quantos livros em média você compra?

ENTREVISTADO 22: Essa é difícil... Depende muito. Ano passado comprei bastante, porque estava em casa sem nada para fazer, então comprei mais do que eu geralmente compro. Mas eu diria que uns 40 ou mais.

Ana Beatriz: E quantos desses são livros de romance?

ENTREVISTADO 22: Todos. (Risos)

Ana Beatriz: Em que formato você prefere ler? Físico, digital....

ENTREVISTADO 22: Prefiro ler no físico.

Ana Beatriz: E por quê?

ENTREVISTADO 22: Eu acho que é melhor... Sentir o livro, colocar na estante... Tem toda uma experiência, por isso eu acho que no digital não tem muito.

Ana Beatriz: Bom, sabemos que você compra livros físicos através de canais digitais.

ENTREVISTADO 22: Uhum.

Ana Beatriz: Por que você faz dessa forma? Quais os benefícios que te fazem escolher esse canal para as suas compras?

ENTREVISTADO 22: Antes da pandemia eu não comprava muito na internet. Eu gostava da experiência de ir na livraria, e também tem uma livraria aqui perto da minha casa. Então não era difícil eu ter acesso aos livros que eu queria comprar. Mas agora que eu não estou saindo de 
casa eu passei a comprar muito na Amazon então é mais confortável porque o livro chega aqui na minha casa e eu não preciso sair e nem ir buscar. Então eu compro em um dia e no dia seguinte praticamente já está aqui em casa, então é bastante cômodo.

Ana Beatriz: Bom, quando você entra no site da Amazon, sua compra já está definida ou a decisão é feita por impulso?

ENTREVISTADO 22: Eu, quando entro, já tenho na minha lista os livros que eu estou querendo comprar no momento. Então quando eu abro e penso, "Ok, hoje eu quero comprar um livro", eu vou naqueles que eu já separei e compro. Mas sempre tem aquela promoção que aparece, ou um livro novo que chama atenção e eu acabo comprando.

Ana Beatriz: E você faz pesquisas em outros marketplaces antes de comprar na Amazon?

ENTREVISTADO 22: Eu fazia, mas agora eu assinei o Amazon Prime, então eu tenho o frete grátis. Então eu agora dou preferência à Amazon até por causa disso.

Ana Beatriz: E o que você buscava nessa pesquisa?

ENTREVISTADO 22: O menor preço. Mas às vezes o frete não compensava.

Ana Beatriz: Com que frequência costuma comprar livros no site Amazon?

ENTREVISTADO 22: Praticamente toda semana. Pelo menos um, toda semana eu estou comprando.

Ana Beatriz: $O$ que te leva a consumir nesse marketplace? Assim, qual o diferencial da Amazon com relação a outros canais digitais que o leva a consumir nela?

ENTREVISTADO 22: Eu não sei por que, mas a Amazon me passa uma segurança muito grande com relação aos produtos dela. Eu já tive problemas com extravio de encomendas e essas coisas, então eles sempre se propuseram a resolver os problemas, seja me mandando outro livro ou me dando o reembolso. Então eu sempre consegui resolver meus problemas... E também os preços deles, geralmente são os mais baixos, pelo que eu vejo... E também o frete, que é grátis. Acaba sendo o que mais pesa.

Ana Beatriz: Quantos livros físicos de romance você comprou através da Amazon? Pensa no último ano, assim... 
ENTREVISTADO 22: Eu acho que eu só compro livros de romance... Então acho que dos 40, no último ano eu comprei 38 na Amazon.

Ana Beatriz: E por qual canal você prefere realizar suas compras na Amazon? Celular, Tablet, Computador...

ENTREVISTADO 22: Às vezes pelo celular, às vezes pelo computador... Eu não tenho uma preferência não.

Ana Beatriz: E o que você mais leva em consideração no momento da compra?

ENTREVISTADO 22: Como que o preço está no dia. Porque na Amazon os preços oscilam bastante também... Principalmente de livro importando, que eu compro muito na Amazon também. Então sempre que o preço está mais baixo eu acabo comprando, porque eu não sei se vai voltar a aumentar... Isso me influência muito no momento da compra.

Ana Beatriz: E você já desistiu de alguma compra de livros online e se sim, o que te fez desistir?

ENTREVISTADO 22: Já! Já desisti... Já aconteceu de eu comprar na internet, estar com a transportadora e a transportadora demorar duas semanas a mais do que eles me deram, eu cancelar e comprar em outro site.

Ana Beatriz: E na Amazon? Você já desistiu de alguma compra de livros online?

ENTREVISTADO 22: Na Amazon não!

\section{ENTREVISTADO 23}

Ana Beatriz: Comecei a gravar aqui, tudo bem?

ENTREVISTADO 23: "Tá" bom!

Ana Beatriz: Queria te agradecer mais uma vez por você estar aqui respondendo as perguntas... Eu sei que leva um tempinho que hoje em dia muitas vezes a gente não tem (Risos).

ENTREVISTADO 23: (Risos) Nada, fico feliz em ajudar!

Ana Beatriz: Vamos começar?

ENTREVISTADO 23: Vamos!

Ana Beatriz: Então primeira pergunta... Em um ano, quantos livros em média você compra?

ENTREVISTADO 23: Ano passado, se eu não me engano eu comprei uns 60 livros. Esse ano acho que eu já comprei uns 10 .

Ana Beatriz: E quantos desses são livros de romance? 
ENTREVISTADO 23: Acho que uns 15, mais ou menos.

Ana Beatriz: Em que formato você prefere ler? Físico, digital....

ENTREVISTADO 23: Eu confesso que eu gosto do físico, mas o Kindle me ganha pela praticidade, sabe? Às vezes eu estou deitada na cama e eu estou lendo um livro de 500 páginas... No Kindle é muito mais confortável. Mas assim, nada me tira a sensação de ter o livro, de estar com o livro, de sentir o livro, de rabiscar o livro... Sou daquelas que rabisca, sabe? Eu não tenho pena do papel. Mas é isso, eu gosto muito do físico, mas acabo me rendendo ao Kindle.

Ana Beatriz: Bom, sabemos que você compra livros físicos através de canais digitais.

ENTREVISTADO 23: Sim.

Ana Beatriz: Por que você faz dessa forma? Quais os benefícios que te fazem escolher esse canal para as suas compras?

ENTREVISTADO 23: Aqui onde eu moro, não tenho livrarias perto sabe? Elas são mais distantes e elas geralmente são caras... E sebo, bom eles são longes e eu tenho implicância com livro que não é novo... Então eu vou na Amazon mesmo porque eu gosto de ter o livro "pelado", que ainda não foi lido. Eu acabo optando pela Amazon mais mesmo por causa do preço. Chato falar isso, mas é a verdade.

Ana Beatriz: Bom, quando você entra no site da Amazon, sua compra já está definida ou a decisão é feita por impulso?

ENTREVISTADO 23: Eu geralmente já tenho uma compra definida sabe? As pessoas comentam comigo de livros que elas gostaram, eu entro lá e compro. Mas já aconteceu de eu estar passeando na Amazon, vi um livro, e compro para conhecer.

Ana Beatriz: E você faz pesquisas em outros marketplaces antes de comprar na Amazon e se sim, o que você busca nessa pesquisa?

ENTREVISTADO 23: Sempre dou uma olhada no Submarino, mas como eu sou assinante do Prime, eu não pago frete na Amazon. Então às vezes até está mais barato na Amazon, mas com o frete ou fica mais caro ou no mesmo preço... Ai acaba que eu sempre opto pela Amazon, porque eu já estou mais acostumada e algumas compras que eu fiz na submarino deram problemas, enfim... Enquanto na Amazon eu nunca tive nenhum, então acaba que eu confio mais.

Ana Beatriz: Com que frequência costuma comprar livros no site Amazon? 
ENTREVISTADO 23: $100 \%$... Não mentira, tem alguns que foram da Submarino, mas dos 60 do ano passado, acho que só 10 eu comprei na Submarino.

Ana Beatriz: 0 que te leva a consumir nesse marketplace? Assim, qual o diferencial da Amazon com relação a outros canais digitais que o leva a consumir nela?

ENTREVISTADO 23: Para mim é a rapidez da Amazon. Já aconteceu de eu comprar o livro na quarta feira e na quinta de manhã o livro já ter chegado. Mas ao mesmo tempo, eu acho complicada essa rapidez, porque teve uma pessoa que teve que se desdobrar pra fazer esse livro chegar essa hora na minha casa sabe? Eu fico me perguntando sobre as nossas expectativas com relações a coisas éticas mesmo, para mim é muito surreal, mas hoje em dia a gente acaba se prendendo a isso. $E$ também a qualidade de como o produto chega. Às vezes ele chega um pouco amassado, mas enfim... papel né? Acontece... Mas nunca tive problemas assim, do livro chegar com aspecto de sujo, de velho... Uma vez só roubaram a transportadora e... Bom, aconteceu, mas na mesma hora falaram que podiam me enviar o dinheiro, falaram que podiam me enviar o livro novamente, tudo certo... O atendimento também é muito bom! Eles respondem muito rápido!

Ana Beatriz: Quantos livros físicos de romance você comprou através da Amazon? Pensa no último ano, assim...

ENTREVISTADO 23: Acho que uns 15 mesmo.

Ana Beatriz: E por qual canal você prefere realizar suas compras na Amazon? Celular, Tablet, Computador...

ENTREVISTADO 23: Eu sempre compro pelo celular.

Ana Beatriz: E o que você mais leva em consideração no momento da compra?

ENTREVISTADO 23: Acho que é o preço, mesmo. E sendo muito sincera, eu julgo muito o livro pela capa. Quando a capa é bonita eu não penso muito não!

Ana Beatriz: E você já desistiu de alguma compra de livros online e se sim, o que te fez desistir?

ENTREVISTADO 23: Ah! Já! Um que eu sempre botava e tirava era It do Stephen King, porque era muito grande e muitas vezes era muito caro... Então assim, eu colocava no carrinho, ficava acompanhando preço. Mas 
eu faço muito isso de colocar no carrinho por que eles notificam quando o preço abaixa né? Então eu fico sempre de olho.

Ana Beatriz: E na Amazon? Você já desistiu de alguma compra de livros online e se sim, o que te fez desistir?

ENTREVISTADO 23: Já! Mesma coisa... Por causa do preço mesmo! 